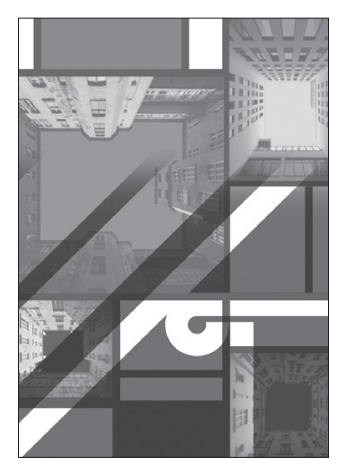

\title{
Mirosław Orzechowski*
}

\section{Między punktem, kreska i plama. Kilka uwag do edukacji architektonicznej opartej na dyscyplinach sztuki}

\author{
Between a dot, a line and a stain - a few remarks on \\ architectural education based on the disciplines of art
}

\section{Wprowadzenie}

Dla większości nauczycieli akademickich prawdopodobnie oczywista jest konieczność zmian w nauczaniu dyscyplin artystycznych na uczelniach architektonicznych. Przyczyny znane są doskonale, najogólniej ujmując, to wejście technik cyfrowych w szeroki obszar prezentacji architektury i zapisu projektowego oraz zmiany ustawowe dotyczące udziału poszczególnych zagadnień w programie studiów. Jest jeszcze jedna przyczyna, bardziej subiektywna i zarazem mniej oczywista, jeszcze niezdefiniowana - zmiany mentalne w kolejnych pokoleniach studentów. Poszukując odpowiedzi na pytanie, jak zmieniać nauczanie dyscyplin artystycznych, aby odpowiadało ono potrzebom i wymaganiom współczesności i kroczącej ku nam błyskawicznie przyszłości, być może warto zwrócić się ku przeszłości? Może odnaleźć trzeba istotę, niezmienny korzeń artyzmu, który będzie odporny na dynamiczną zmienność współczesności?

Próbując odpowiedzieć na te pytania, trzeba przypomnieć Bauhaus, jego twórców i wykładowców. Był to ruch o wyjątkowo silnym oddziaływaniu, który zaważył na kolejnym wieku kształtowania architektury. Warto może sięgnąć do jego idei i zaszczepić je dzisiaj, trochę zapomniane, zakurzone i przysłonięte upływem czasu, od nowa odkryć punkt, linię i płaszczyznę. Odnosząc się do

* ORCID: 0000-0002-1704-8946. Wydział Architektury Politechniki Warszawskiej / Faculty of Architecture, Warsaw University of Technology, e-mail: miroslaw.orzechowski@pw.edu.pl

\section{Introduction}

For the majority of academic teachers, it is probably obvious that there is a need to change the teaching of artistic disciplines at architectural universities. The reasons are well known. Generally speaking, it refers to the implementation of digital techniques in a wide area of presentation of architecture and design record, as well as statutory changes regarding the participation of individual issues in the study program. There is one more reason, more subjective and at the same time less obvious, as yet undefined - mental changes in successive generations of students. Looking for an answer to the question of how to change the teaching of artistic disciplines so that it would correspond to the needs and requirements of the present time and the future that is rapidly approaching us, perhaps it is worth to turn to the past? Perhaps we need to find the essence, the unchanging root of artistry, which will be resistant to the dynamic changeability of modern times.

When trying to answer these questions, it is necessary to recall Bauhaus, its creators and lecturers. It was a movement with an exceptionally strong influence that affected the next century of shaping architecture. Perhaps it is worth coming back to its ideas, which are a bit forgotten, dusty, and obscured by the passage of time, and instill them today, in order to rediscover the point, line and plane. Referring to the Bauhaus on its $100^{\text {th }}$ anniversary, it can be discovered that the activities which are carried out at the Faculty of Architecture of the Warsaw University of Technology (FA WUT), somehow resulting from 
Bauhausu w 100-lecie jego powstania, daje się odkryć, że działania prowadzone na Wydziale Architektury Politechniki Warszawskiej (WA PW), wynikające poniekąd z tradycji wydziału, mają wiele wspólnego z ideami głoszonymi przez starszych kolegów wiek temu. Celem tej wypowiedzi jest zatem ukazanie znaczenia włączania dyscyplin artystycznych do projektowania architektonicznego na przykładzie wybranych zajęć projektowych prowadzonych od kilku lat na WA PW. Należy oprzeć się przy tym właśnie na wskazanych wspólnych założeniach Bauhausu i warszawskiej uczelni.

\section{Materialy}

Prowadzony przez autora tej pracy od kilku lat na pierwszym semestrze studiów magisterskich projekt na etapie poszukiwania idei jest oparty na studiach artystycznych. Pomysł takiej formuły zajęć kiełkował od dłuższego czasu, a zaczął być werbalizowany już kilkanaście lat temu, podczas dorocznego pleneru w Kazimierzu Dolnym. W 2015 r. w jednej z grup studenckich rozpoczęto zajęcia zatytułowane „Projekt miejsca pamięci”. W pierwszej ich odsłonie studenci mieli swobodę wyboru metody pracy, a zespół prowadzący skupił się na temacie miejsca pamięci i osobie upamiętnianej, którą był książę Ksawery Drucki-Lubecki. Skoncentrowano się na placu Bankowym w Warszawie. W efekcie doświadczeń $\mathrm{z}$ tego pilotażowego semestru powstał program obejmujący istotny udział dyscyplin artystycznych $\mathrm{w}$ procesie powstawania projektu. Zaczął on funkcjonować w pełni ukształtowany od 2016 r., od tego czasu zbierane są kolejne doświadczenia i jest stale modyfikowana metoda pracy ze studentami. Zespół prowadzący zajęcia opiera się przy tym na doświadczeniach dydaktycznych, które ukształtowały się w Pracowni Rysunku, Malarstwa i Rzeźby w Zakładzie Dziedzictwa Architektonicznego i Sztuki WA PW. Tradycją jednostki było od początku jej powstania w $1915 \mathrm{r}$. uniwersalne traktowanie wszystkich dyscyplin artystycznych w tworzeniu dzieła architektonicznego.

Sięgając do spuścizny warszawskiego Wydziału Architektury, warto odwołać się do słów prof. Zygmunta Kamińskiego: Goraco pragnąem współuczestniczyć $w$ dziele ksztatcenia młodych pokoleń architektów, aby na moim odcinku współdziałać $w$ formowaniu typu architekta doceniajacego wartość zagadnień plastycznych, znawcy ich i miłośnika, zdolnego do inicjatywy i mecenatu w zakresie właściwego stosowania malarstwa, rzeźby, witrażu, mozaiki, tkaniny artystycznej, ceramiki itp. w projektach architektonicznych. A więc takiego architekta, który przyszedtszy do głosu, umiałby dobrać właściwe zespoty artystów plastyków o różnorodnych klasyfikacjach zawodowych, aby w ten sposób otworzyć im szerokie pole artystycznej pracy twórczej dla dobra rozwoju i postępu sztuki w naszej Ojczyźnie [1, s. 504] ${ }^{1}$.

\footnotetext{
${ }^{1}$ Kamiński wielokrotnie odwoływał się do współudziału przedstawicieli różnych dyscyplin sztuk w procesie edukacji i tworzenia architektonicznego. W zgodzie z tym zbudował w 1915 r. program nauczania rysunku dla studentów architektury na WA PW. Por. [2].
}

the tradition of the faculty, have a lot in common with the ideas promoted by older colleagues a century ago. The aim of this statement is, therefore, to show the importance of incorporating artistic disciplines into architectural design on the example of selected design classes which have been conducted at the Warsaw University of Technology for several years. At the same time, we should take advantage of the indicated assumptions which are common for Bauhaus and the Warsaw university.

\section{Materials}

The project, which has been conducted for several years in the first semester of MA studies by the author of this paper, at the stage of searching for ideas, is based on artistic studies. The idea of such a formula of classes had been sprouting for a long time and it began to be verbalized over a dozen years ago during the annual openair event in Kazimierz Dolny. In 2015, one of the student groups started a class entitled "Project of a memorial site". In the first edition, the students had the freedom to choose the method of work and the leading team focused on the subject of the memorial site and the commemorated person, i.e., Prince Ksawery Drucki-Lubecki. The focus was on Bankowy Square in Warsaw. As a result of the experiences from this pilot semester, a program, which included a significant participation of artistic disciplines in the process of creating a project, was created. It started to function fully developed in 2016. Since then new experiences have been gathered and the method of working with students has been constantly modified. The team conducting the classes uses the didactic experience which was developed in the Studio of Drawing, Painting and Sculpture at the Department of Architectural and Art Heritage of the Warsaw University of Technology. The tradition of the unit, since its establishment in 1915, was the universal treatment of all art disciplines in creating an architectural work.

When referring to the legacy of the FA WUT, it is worth quoting the words of Professor Zygmunt Kamiński: I was eager to participate in the education of young generations of architects to help me shape the type of an architect appreciating the value of art, an expert and an enthusiast, capable of initiative and patronage in the proper use of painting, sculpture, stained glass, mosaic, artistic fabric, ceramics etc. in architectural projects. This is an architect who, having come to the fore, would be able to choose the right groups of visual artists with various professional classifications, in order to open a wide field of artistic creative work to them for the good of development and progress of art in our homeland [1, p. 504] $]^{1}$.

After all, this is a shared voice with Walter Gropius, who wrote: The Bauhaus aimed at the training of people possessing artistic talents as designers in industry and handicrafts, as sculptors, painters and architects.

\footnotetext{
1 Kamiński made many references to the participation of representatives of various disciplines of arts in the process of education and architectural creation. In line with this, in 1915 he built a curriculum of drawing classes for students of architecture at the WUT. Cf. [2].
} 
Czyż nie jest to wspólny głos z Walterem Gropiusem, który pisał: Założeniem Bauhausu było przygotowanie osób utalentowanych artystycznie do roli projektantów $w$ przemyśle i rzemiośle, a także rzeźbiarzy, malarzy oraz architektów. Podstawe stanowiło obszerne, uporzadkowane szkolenie obejmujace wszystkie postaci rękodzieła [...] [3, s. 30 $]^{2}$.

Taki był też kierunek tworzenia architektury [5] początków i 1 . połowy XX w. ${ }^{3}$

Coś wydarzyło się na przestrzeni wieku, co doprowadziło do oderwania współczesnych twórców od tych - jakże pięknych - idei, które przecież nie były jedynie ideami, a uzyskały liczną reprezentację w postaci wybitnych dzieł architektonicznych, również w międzywojennej Polsce, jak choćby przykłady modernistycznej architektury z Powszechnej Wystawy Krajowej w Poznaniu w 1929 r.: Pawilon Nawozów Sztucznych Szymona Syrkusa, Pawilon Centrocementu Bohdana Lacherta i Józefa Szanajcy, Pawilon Domu Mody Bogusława Herse autorstwa Bohdana Pniewskiego czy Pawilon Ministerstwa Skarbu grupy Praesens czy wiele późniejszych dzieł tych i innych autorów [6].

Nie do końca trafnie Bauhaus utożsamiany jest przez odbiorców architektury, w tym również osoby o odpowiednim przygotowaniu zawodowym, przede wszystkim jedynie z prostopadłościennymi budynkami-pudełkami reprezentującymi tzw. styl międzynarodowy. Zasadna wydaje się głębsza refleksja nad tym, co pisali o twórczości projektowej i artystycznej założyciel szkoły i jeden z zaproszonych do jej prowadzenia artystów. Warto zatem przytoczyć dwa, jakże znaczące cytaty. Trzeba też pozwolić sobie na komfort głębszej analizy zawartych w nich treści. Przede wszystkim wniknąć w myśl Waltera Gropiusa zawartą w słowach: Jeśli zaś chodzi o moje doświadczenie, to gdy budowałem w Stanach Zjednoczonych pierwszy dom - mój własny - postanowiłem właczyć do planu te cechy architektonicznej tradycji Nowej Anglii, które wydawaty mi się wciaż żywe $i$ odpowiednie. Połaczenie lokalnego ducha ze współczesnym podejściem do projektowania doprowadziło do powstania domu, którego nigdy nie skonstruowałbym w Europie, w całkowicie odmiennym klimacie oraz kontekście technicznym i psychologicznym. Starałem się podejść do tego zadania tak, jak czynili to pierwsi budowniczowie na tych terenach, gdy, robiąc najlepszy użytek z dostęnych im środków, projektowali proste budynki o wyrazistych cechach, zdolne sprostać warunkom klimatycznym, a równocześnie wyrażajace nastawienie społeczne mieszkańców [3, s. 13] $]^{4}$.

\footnotetext{
${ }^{2}$ Dostrzeżenie specjalnej roli dyscyplin sztuki w nowej architekturze, w pewnym sensie wyzwolonych, było charakterystyczne dla Bauhausu, szczególnie w początkowym okresie funkcjonowania. Analizując Bauhaus, nie wolno pomijać zmian dyrektorów i charakteru samej szkoły. Por. [4].

3 U Le Corbusiera znajdujemy słowa: Panowie malarze i rzeźbiarze, mistrzowie współczesnej sztuki, którzy znosicie tyle drwin i spotykacie się z taka obojętnościa, oczyśćcie domy, połączcie wasze wysilki, by odbudować miasta. Wasze dzieła pojawia sie wówczas $w$ ramach epoki i będziecie powszechnie rozumiani i podziwiani. Architektura potrzebuje waszej uwagi. Zmierzcie się z problemem architektury [5, s. 74]. Oparcie nowej architektury na nowych kierunkach sztuki wydawało się współczesnym najlepszym, jedynym kierunkiem rozwoju.

${ }^{4}$ Czyż nie jest to kontekstualizm?
}

A complete co-ordinated training of all handicrafts $[\ldots]$ $[3, \text { p. } 30]^{2}$.

This was also the direction in creating the architecture [5] of the $1^{\text {st }}$ half of the $20^{\text {th }}$ century ${ }^{3}$.

In the past, there was something which led to the separation of contemporary artists from these - how beautiful - ideas, which were not only ideas, but were widely represented in the form of outstanding architectural works, also in interwar Poland, such as examples of modernist architecture from the Universal National Exhibition in Poznań in 1929: Fertilizer Pavilion by Szymon Syrkus, Centrocement Pavilion by Bohdan Lachert and Józef Szanajca, Bogusław Herse Fashion House Pavilion by Bohdan Pniewski or the Pavilion of the Ministry of Treasury by the Praesens group or many later works by these and other authors [6].

The Bauhaus, not quite accurately, is identified by the recipients of architecture, including people with proper professional preparation, mainly only with cuboidal buildings-boxes representing the so-called international style. A deeper reflection on what the founder of the school and one of the artists invited to run the school wrote about the design and artistic creativity, seems justified. Therefore, it is worth recalling two very significant quotes. One should allow oneself the comfort of a deeper analysis of their content. First of all, one should penetrate the mind of Walter Gropius contained in these words: As to my practice, when I built my first house in the U.S.A. - which was my own - I made it a point to absorb into my own conception those features of the New England architectural tradition that found still alive and adequate. This fusion of the regional spirit with a contemporary approach to design produced a house that I would never have built in Europe with its entirely different climatic, technical and psychological background. I tried to face the problem in much the same way as the early builders of the region had faced it when, with the best technical means at their disposal, they built unostentatious, clearly defined buildings that were able to withstand the rigors of the climate and that expressed the social attitude of their inhabitants $[3, \text { p. 13] }]^{4}$.

In the context of the contemporary, rather superficial understanding of Bauhaus, the sense derived from the above words may be surprising, supporting designing on heritage, local traditions and the context in areas beyond visual or stylistic issues. The views of Wassily Kandinski are similar in their deepest sense:

\footnotetext{
2 The perception of the special role of the disciplines of art, liberated in a sense, in new architecture was characteristic of the Bauhaus, especially in its initial period. When analyzing the Bauhaus, one cannot ignore the changes in the directors and the nature of the school itself. Cf. [4].

3 The following words of Le Corbusier can be found: Painters and sculptors, champions of the art of to-day, you who have to bear much mockery and who suffer so much indifference, let us purge our houses, give your help that we may reconstruct our towns. Your works will then be able to take their place in the framework of the period and you will everywhere be admitted and understood. Tell yourselves that architecture has indeed need of your attention. Do not forget the problem of architecture $[5$, p. 74$]$. Basing the new architecture on new directions of art seemed to contemporary authors to be the best and the only direction of development.

4 Isn't that contextualism?
} 
W kontekście współczesnego, dość powierzchownego pojmowania Bauhausu może zadziwić sens płynący z powyższych słów, oparcie w projektowaniu na dziedzictwie, tradycjach lokalnych i kontekście w obszarach wykraczających poza zagadnienia wizualne czy stylistyczne. Podobne w najgłębszym swoim sensie są poglądy Wassilego Kandinskiego:

$W$ niniejszej publikacji rozpatrywane będa dwa elementy podstawowe stanowiace najmniejszy zalażek każdego dzieła sztuki malarskiej, niezbędny poczatek jego istnienia. Stanowia one zarazem podstawe odrębnego gatunku artystycznego - grafiki. Tak więc wypada zaczać od praelementu malarstwa - od punktu. Ideałem każdego badania jest:

1. staranne analizowanie poszczególnych zjawisk - izolowanie,

2. badanie wzajemnego oddziaływania zjawisk na siebie-konfrontowanie,

3. wyciaganie wniosków ogólnych z obydwu wymienionych sposobów postępowania $[7, \text { s. 20] }]^{5}$.

Porównując założenia dla ,zalążku dzieła sztuki malarskiej” z etapem wstępnym procesu projektowego w obszarze architektury, dostaje się pełną spójność obydwu metod. Architekci również zaczynają od analizy poszczególnych zjawisk - zagadnień programu funkcjonalnego, uwarunkowań lokalizacji, wymagań planistycznych i urbanistycznych, kontekstów, w tym szeroko pojmowanego dziedzictwa i tradycji budowlanej. Co ciekawe, $\mathrm{w}$ procesie analiz projektowych też następuje ,izolowanie” zagadnień, a następnie ich „konfrontowanie”, sprawdzanie wzajemnych oddziaływań. Procesy te prowadzą do wniosków, wytycznych dla dalszych działań w projektowaniu architektonicznym.

\section{Metoda}

Wprowadzenie dyscyplin sztuki na WA PW zostało zaszczepione na końcowym etapie studiów w ramach projektu architektonicznego w kontekście śródmiejskim, odbywającego się na pierwszym semestrze studiów magisterskich na studiach dwustopniowych, odpowiadającym dziewiątemu semestrowi studiów jednolitych. Tytuł zajęć brzmi: „Miejsce Pamięci księcia Ksawerego Druckiego-Lubeckiego, Plac Bankowy w Warszawie". Temat jest poświęcony studium formy architektonicznej upamiętniającej wybitną osobę życia polityczno-ekonomicznego Królestwa Kongresowego. Studium projektowe przeprowadzane jest w oparciu o koncepcje przestrzenne stworzone na podstawie studiów z dyscyplin artystycznych, rysunku, grafiki, malarstwa i rzeźby ${ }^{6}$.

5 Podwaliny analizy sztuki zawarte w dziele Kandinskiego miały głęboki wpływ na późniejszy rozwój sztuk, wydają się stale aktualne, ponadczasowe.

6 Projekt prowadzi zespół pod kierunkiem dr. hab. inż. arch. Mirosława Orzechowskiego, prof. PW, w składzie: dr inż. arch. Grzegorz Rytel - odpowiedzialny za zagadnienia miejsca pamięci; mgr sztuki, artysta rzeźbiarz Marcin Nowicki - odpowiedzialny za zagadnienia rzeźbiarskie; dr sztuki, artysta malarz Radosław Jan Balcerzak - odpowiedzialny za zagadnienia malarskie i graficzne. Prace są recenzowane przez mgr. inż. arch. Krzysztofa Mycielskiego.
This book will deal with two basic elements which are the very beginning of every work of painting, and without which this beginning is not possible. At the same time, they constitute the conclusive material for an independent kind of painting - graphic. We must, therefore, start here with the proto-element of painting - the Point. The ideal of all research is:

1. precise investigation of each individual phenomenon - in isolation,

2. the reciprocal effect of phenomena upon each other - in combinations,

3. general conclusions which are to be drawn from the above two divisions $[7, \text { p. } 20]^{5}$.

Comparing the assumptions for the "seed of the painting art" with the initial stage of the design process in the field of architecture, we get full consistency of both methods. Architects also start with the analysis of individual phenomena - issues of the functional program, location conditions, planning and urban requirements, contexts, including the broadly understood heritage and building tradition. Interestingly, in the process of design analyses, issues are also "isolated" and then "confronted" and their mutual interactions are checked. These processes lead to conclusions and guidelines for further actions in architectural design.

\section{Method}

The introduction of art disciplines at FA WUT was instilled at the final stage of studies as part of an architectural design in the downtown context, taking place during the first semester of two-cycle studies, corresponding to the ninth semester of uniform studies. The title of the class is: "Prince Ksawery Drucki-Lubecki Memorial Site, Bankowy Square in Warsaw". The topic is devoted to the study of an architectural form commemorating an outstanding person of political and economic life in Congress Poland. The design study is carried out on the basis of spatial concepts created on the basis of studies in artistic disciplines, drawing, graphics, painting and sculpture ${ }^{6}$.

The process may be divided into three stages. It is preceded by a fairly extensive introduction to the method, to which separate classes are devoted. They include a lecture describing the manner of its implementation and the essence of individual study steps as well as formal conditions, corrections, consultations, and rules for assessing the effects of the work. The first stage consists of studies and analyses devoted to the collection of input materials for designing, which ends with the formulation of conclusions. The second stage consists of artistic studies on the recording of the conclusions formulated during the

5 The foundations of the art analysis contained in Kandinski's work had a profound influence on the subsequent development of arts, hence, they seem to be all the time relevant and timeless.

6 The project is being conducted by a team led by Mirosław Orzechowski, D.Sc. Eng. of Architecture, professor at WUT composed of: Grzegorz Rytel, PhD Eng. of Architecture - responsible for the memorial sites issues; sculptor artist Marcin Nowicki, M.A. in Arts - responsible for sculpting issues; painter Radosław Jan Balcerzak, $\mathrm{PhD}$ in Art - responsible for the issues of painting and graphics. Papers are reviewed by Krzysztof Mycielski, M. Eng. of Architecture. 
Praca nad projektem podzielona jest na trzy etapy. Poprzedza je dość obszerne wprowadzenie do metody, czemu poświęcone są odrębne zajęcia przeznaczone na wykład opisujący sposób jej realizacji, istotę poszczególnych kroków studialnych oraz uwarunkowań formalnych, korekt, konsultacji i zasad oceniania efektów pracy. Pierwszy etap stanowią studia i analizy poświęcone zbieraniu materiałów wejściowych do projektowania zakończone sformułowaniem wniosków. Etap drugi to studia artystyczne nad zapisem wniosków sformułowanych podczas pierwszego etapu. Trzeci etap polega na interpretacji zapisów artystycznych w taki sposób, aby ich treści przenieść na język architektury, doprowadzając do powstania konkretnych rozwiązań projektowych. Odrębną część zajęć, bezpośrednio przed zakończeniem projektu i wystawą końcową, stanowi omówienie sposobu prezentacji wyników wykonanych studiów, retrospekcja kolejnych etapów i wskazanie głównej struktury procesu projektowego. Skupienie uwagi na zrozumieniu idei metody, a nie wyłącznie na jej realizacji, stanowi dla zespołu dydaktycznego najistotniejszy składnik zadania.

Omawiana metoda dydaktyczna składa się - jak wspomniano $-\mathrm{z}$ trzech etapów prac studialnych oraz ściśle sformułowanych zasad prezentacji projektów i zasad ich oceny. Dla zilustrowania kolejnych etapów pracy ze studentami zamieszczono ilustracje przykładowych prac studenckich wykonanych podczas ćwiczeń ${ }^{7}$.

Po przedstawieniu na pierwszych zajęciach metody i zasad ich prowadzenia studenci otrzymują podkład geodezyjny terenu lokalizacji projektu i odbywają wizję w terenie. Obchód podzielony jest na trzy części. Najpierw grupa poznaje przestrzenie wiodące ze wszystkich kierunków na plac Bankowy, szczególną uwagę zwraca się przy tym na dostrzeganie pierwszych urbanistycznych i architektonicznych przesłanek anonsujących wchodzenie w obszar lokalizacji projektu. Skupienie uwagi na relacjach w skali miasta ma przy tym najistotniejsze znaczenie. Kolejny etap to obejście całego terenu ze szczególnym zwróceniem uwagi na skalę wnętrza urbanistycznego, skalę poszczególnych obiektów i powiązania widokowe z obiektami drugiego planu spoza terenu lokalizacji. Ważne dla tego etapu jest poświęcenie większej ilości czasu na powracanie w te same miejsca, ponowne ich analizowanie etc. Grupa spędza nieco czasu na dyskusji poświęconej głównym spostrzeżeniom dotyczącym zagadnień skali, stylu, funkcji, ruchu, atmosfery miejsca. Studenci wskazują, co przykuło ich uwagę zarówno w skali detalu, jak i całości przestrzeni placu. Kończąc wizję w terenie, studenci otrzymują zalecenie wykonania samodzielnych analiz o różnych porach doby, również nocą przy sztucznym oświetleniu. Podczas obchodu powstają szkice z natury, fotografie i notatki poświęcone cechom zastanej przestrzeni. Następnie na podstawie otrzymanego podkładu geodezyjnego placu Bankowego (SURE) dokonują analizy uwarunkowań technicznych, mediów, komunikacji. Zapoznają się z osobą upamiętnia-

7 Ze względu na brak możliwości prezentacji w niniejszym tekście wszystkich wykonanych projektów zdecydowano się zamieścić wybór zróżnicowanych prac bez ich wartościowania. first stage. The third stage consists of interpretation of the artistic records in such a way as to transfer their content into the language of architecture, leading to the creation of specific design solutions. A separate part of the course, immediately before the end of the project and the final exhibition, includes presentation of the results of the studies performed, a retrospection of the subsequent stages and indication of the main structure of the design process. Focusing on understanding the idea of the method, and not only on its implementation, is the most important component of the task for the teaching team.

The teaching method under discussion - as it has already been mentioned - consists of three stages of study work and a strictly formulated rules for the presentation of projects and the rules for their evaluation. To illustrate the subsequent stages of work with students, illustrations of exemplary student works made during the exercises ${ }^{7}$ have been enclosed herein.

After presenting the methods and principles of their conduct during the first classes, students receive a geodetic base of the project location area and take a field vision. The inspection is divided into three parts. First, the group gets to know the spaces leading to Bankowy Square from all directions, paying special attention to the first urban and architectural premises announcing entering into the area of the project location. Focusing on relations on a city scale is of the greatest importance. The next step is to walk around the entire area, paying special attention to the scale of the urban interior, the scale of individual objects and visual connections with secondary plan objects from outside of the site. For this stage it is important to spend more time returning to the same places, analyzing them again, etc. The group spends some time discussing the main findings on issues of scale, style, function, movement, and atmosphere of the place. Students indicate what caught their attention, both in terms of detail and the entire space of the square. At the end of the field vision, students are recommended to carry out independent analyses at different times of the day, also at night with artificial lighting. During the inspection, sketches of nature, photographs and notes devoted to the features of the existing space, are created. Then, on the basis of the received geodetic background of Bankowy Square (SURE), they analyze the technical conditions, media and communication. They get acquainted with the commemorated person and perform a biographical and historical analysis of the character (Fig. 1). On the basis of own studies and searches of available archival materials they carry out a historical and architectural analysis of development of Bankowy Square and the surrounding area (Fig. 2). At the same time, on the basis of a field vision, they also analyze spatial connections on a city scale (Fig. 3) and a stylistic study of building development of the square and the neighboring buildings. All studies lead to the indication of conclusions to make a decision on the form of commemoration. At the same time, each

\footnotetext{
7 Due to the fact that it is not possible to present all the projects in this text, we decided to include a selection of different works without any evaluation.
} 


\section{analiza personalna: książę Franciszek Ksawery Drucki-Lubecki}

$1772,1793,1795$ kolejne rozbiory Polski

1807 utworzenie Księstwa Warszawskiego prze Napoleona I

1814-1915 Kongres Wiedeński - zmiany terytorialne po wojnach napoleońskich

1815-1832 Królestwo Polskie (kongresowe) utworzone na mocy traktatu rosyjsko-austriacko-pruskiego i połączone unią personalną z Imperium Rosyjskim 1830-1831 powstanie listopadowe

\section{Sytuacja Królestwa Polskiego po roku 1815:}

ok $70 \%$ dochodu narodowego stanowi rolnictwo oparte na sys. feudalnym wyniszczenie przez działania wojenne

państwa zaborcze oraz Saksonia składają roszczenia wobec państwa polskiego kraj na skraju bankructwa

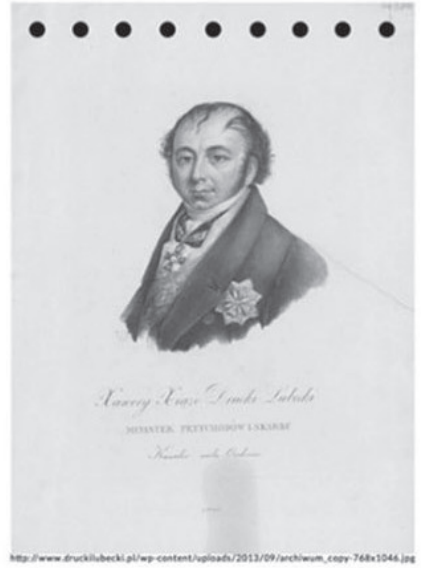

1821 Drucki-Lubecki mianowany

1827 ,plan Lubecki-Lempe

1828 załotenie Banku Polskiego 1830 cztonek delegacij do Cara zm.1846 Sankt Petersburg 1800 dymisja z wojska z powodow zdrowotnych,
przeprowadzka na Litwe 1816 komisarz w trojpanstwowej Komisji Likwidacyjnej

\section{KONSERWATYSTA}

을 kealizm - silne relacje z carem i poleganie na jego przychylności dla sprawy polskiej zarzucany mu był lojalizm carowi

POLITYK

REALISTA

$a$
$a$
0
0
0
a
0

zniesienie ceł na handel z Rosja

twarda polityka fiskalna i egzekwowanie długów - za to niepopularny i nielubiany

modernizacja i oddłużenie majątków - "dźwignia nie tylko dla gospodarki, ale dla prawości społeczeniśtwa"

powstanie Towarzystwa Kredytowego Ziemskiego oraz Banku Polskiego

rozwój przemysłu - górniczego, hutniczego, włokienniczego

PRZEDSIĘBIORCA

edukacja i służba wojskowa wśród elit cesarstwa rosyjksiego

ŻOKNIERZ

wojsk rosyjskich

ofiara intryg Mikołaja Nowosilcowa, faktycznego carskiego namiestnika w Królestwie

wielki sukces i tryumf jako komisarz Komisji Likwidacyjnej:

Prusy zostały zobowiązane do zwrotu Królestwu $3.7 \mathrm{mln}$ zł, a Austria zobowiązała się dostarczyć sól z Wieliczki o wartości $30,8 \mathrm{mln} z \nmid$

\section{DYPLOMATA}

przeciwnik powstania listopadowego, jednak uczestniczył w delegacji do cara

PATRIOTA

zostawił w kasie skarbu państwa $34 \mathrm{~m} l n$ złł choć na wyjazd z Polski sam musiał sprzedać swój majątek

Il. 1. Karty z analizy

osoby księcia.

Synteza hasłowa zapisana w prezentacji przedstawianej przez studenta i w zeszycie A3 (oprac. A. Rusinowska, źródło: archiwum WA PW)

Fig. 1. Cards with the analysis of the prince's persona.

A keyword synthesis included in the presentation prepared by a student and in A3 notebook (elaborated by A. Rusinowska, source: archive of FA WUT) ną i wykonują analizę biograficzno-historyczną postaci (il. 1). Na podstawie studiów własnych, kwerendy dostępnych materiałów archiwalnych przeprowadzają analizę historyczno-architektoniczną rozwoju placu Bankowego i okolic (il. 2). Równocześnie m.in. na podstawie wizji w terenie wykonują też analizy powiązań przestrzennych w skali miasta (il. 3) oraz badanie stylistyczne zabudowy placu i obiektów sąsiadujących. Wszystkie studia prowadzą do wskazania wniosków do podjęcia decyzji o formie upamiętnienia. Jednocześnie każda analiza zostaje podsumowana krótkim zapisem o charakterze hasła ${ }^{8}$

8 Zwerbalizowanie wniosków w formie krótkiego hasła, wręcz dwu- lub jednowyrazowego, o charakterze przymiotnikowym ma szczególne znaczenie dla syntetyzowania zdobytych informacji. Doprowa- analysis is summed up with a short record in the form of a slogan ${ }^{8}$ defining the features that should be included in the designed shape of the Bankowy Square. The results of this stage are recorded in the form of a digital presentation and presented to the group by subsequent students in the form of a 10-minute commented visual presentation. Each statement is discussed by the group and the tutor. This form of a series of micro-lectures constitutes an important

\footnotetext{
8 Verbalizing conclusions in the form of a short slogan, consisting even of two or one word, in the form of an adjective is of particular importance for the synthesis of the obtained information. Bringing the process of information processing for individual issues to be written in one or two words triggers the necessity to specify, carry out full analysis and a synthesis of data, forcing to consider and make an in-depth reflection.
} 
analiza historyczna: Plac Bankowy, Warszawa ZANIK ULICY RYMARSKIEJ UTRATA DOMKNIIZĆ

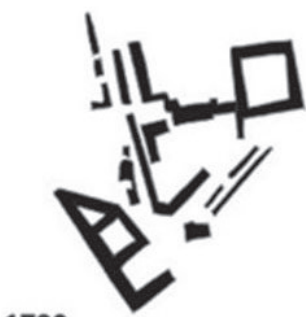

1790

brak zaryowanego placu, rospornawains jest

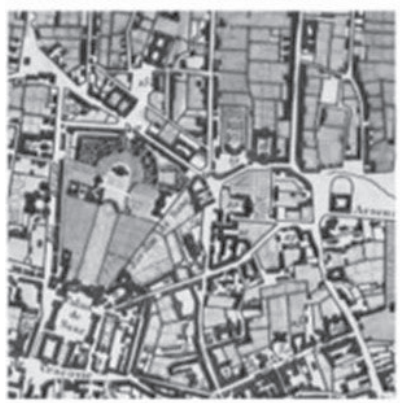
PRZESTRZEŃ NIE IDENTYFIKOWALNA JAKO PLAC

UTRATA DOMKNIIC

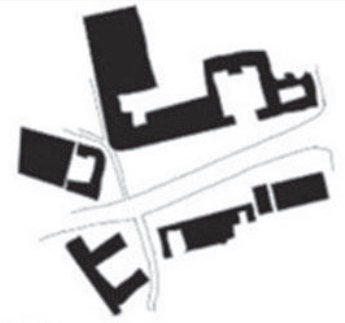

2019

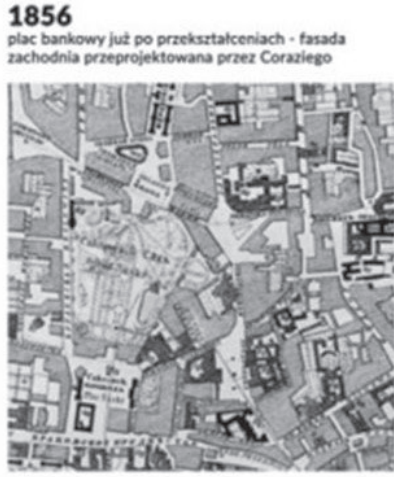

Do powojennej prapodowie ranikta ulica Rymarska,

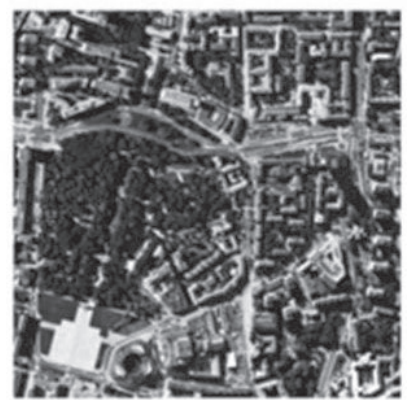

analiza historyczna: Plac Bankowy, Warszawa

OS WIDOKOWA TRASA PIESZA EACZACA OGRODY KRASIŃSKICHISASKI POWSTANIE OSIEDLA MIESZKANIOWEGO

Il. 2. Karty z analizy historycznej. Synteza hasłowa zapisana w prezentacji przedstawianej przez studenta i w zeszycie A3 (oprac. A. Rusinowska, źródło: archiwum WA PW)

Fig. 2. Historical analysis cards. A keyword synthesis included in the presentation prepared by a student and in A3 notebook

(elaborated by A. Rusinowska, source: archive of FA WUT)

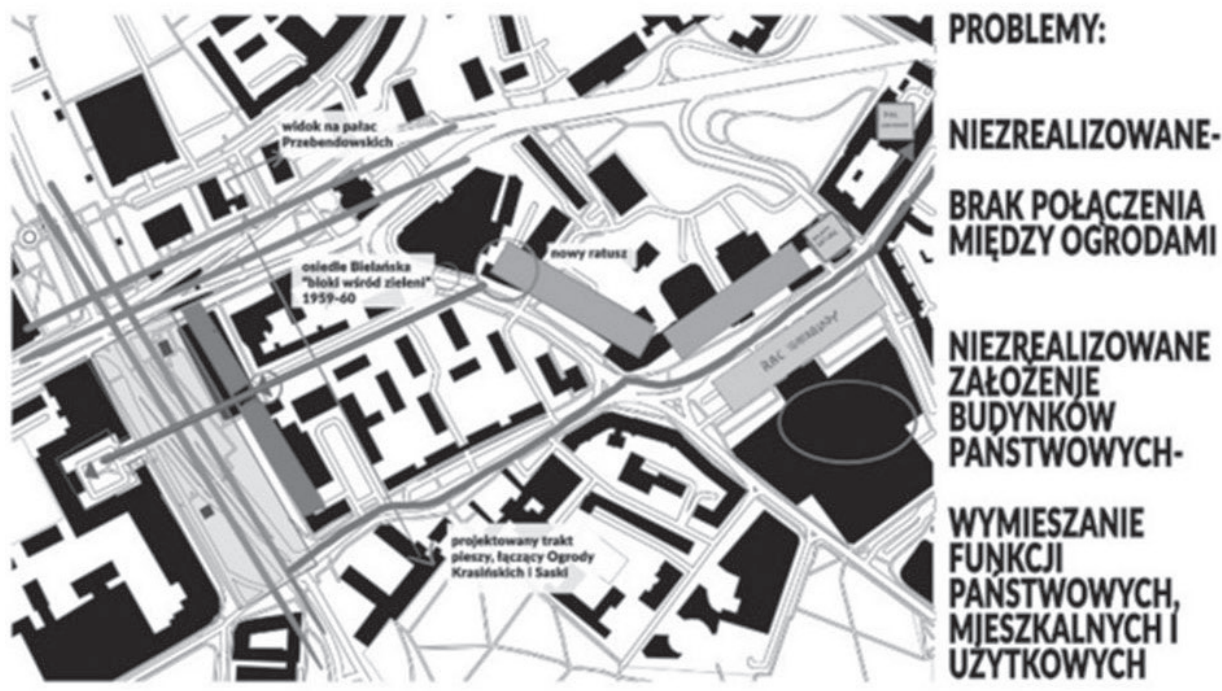

1951 Bolesław Bierut, "Szescioletni plan odbudowy Warszawy" - okolica miała pełnic role reprezentatywne; zmianie ulegt kształt placu, zachodnia pierzeje odbudowano w formie sprzed wojny, natomiast dyskutowano nad planami wschodniej częsci placu. Istotna rolę odegrały nowo budowane drogi, ul. Marszałkowska I trasa WZ określającego cechy, które powinny zostać zawarte w projektowanym kształcie placu Bankowego. Wyniki tego etapu zapisywane są w formie prezentacji cyfrowej i przedstawiane grupie przez kolejne osoby w postaci 10-minutowej komentowanej prezentacji wizualnej. Każda wypowiedź jest omawiana przez grupę i prowadzącego. Taka forma serii mikroreferatów stanowi ważne podsumowanie i jest okazją do konfrontacji zainteresowań i klarujących

dzenie procesu przetworzenia informacji dla poszczególnych zagadnień do zapisu w jednym lub dwóch słowach wyzwala konieczność konkretyzowania, pełnej analizy i syntezy danych, zmusza do zastanowienia i pogłębionej refleksji. summary and is an opportunity to confront the interests and the clearing up predispositions of individual participants of the classes. Exchange of views on defined problems can be fruitful and may have an impact on further own analyses. This usually confirms students' records of the main ideas, features, design indications, and sometimes allows students to formulate them more precisely. It is also an opportunity to check in practice the completeness of the input analyses carried out by individual people ${ }^{9}$.

9 On this occasion, the technical side and methods of conducting this type of presentation are also discussed, paying attention to their strengths and weaknesses, also in the linguistic area. 
analiza zabudowy: Plac Bankowy, Warszawa

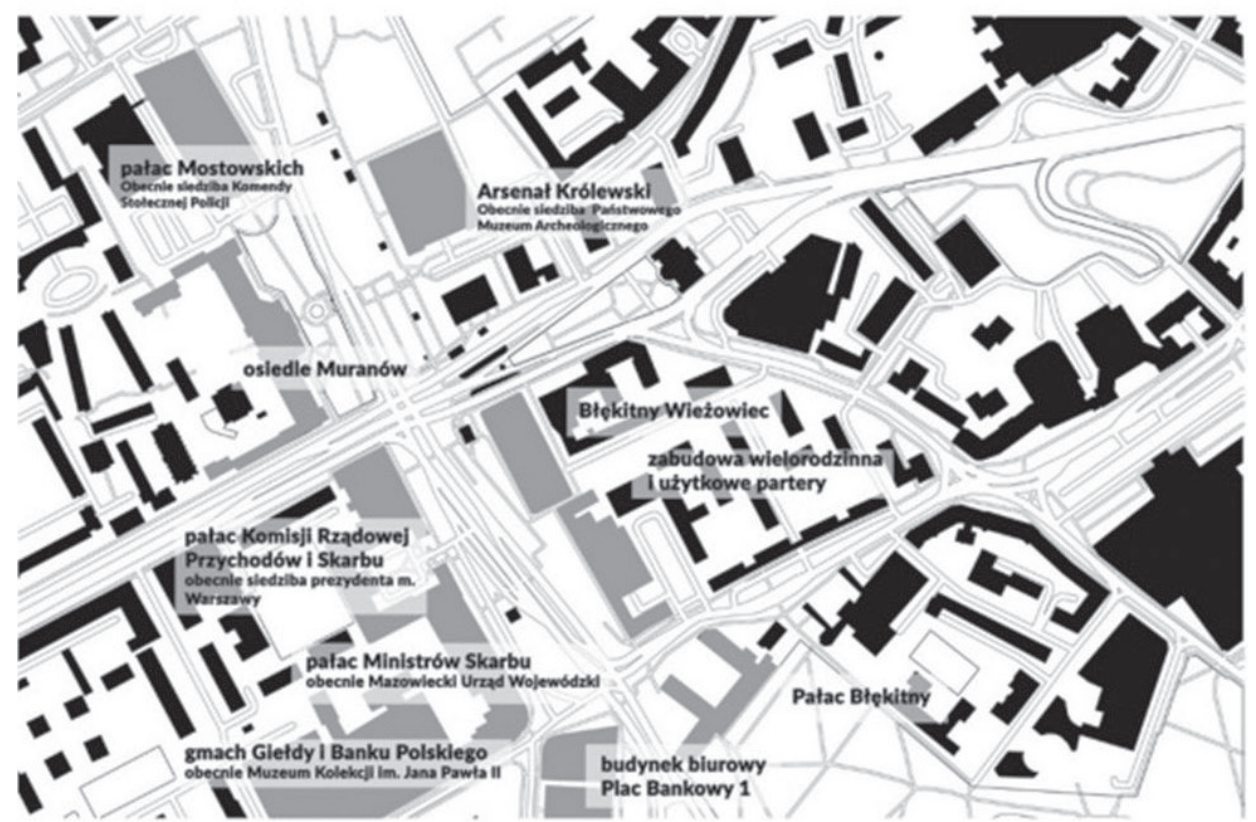

analizy urbanistyczne: Plac Bankowy, Warszawa

SILNIEJSZE POWIAZANIA PRZESTRZENNE DOMKNIĘCIEIKADROWANIE WIDOKOWW USPOKOJENIE KOMUNIKACJI

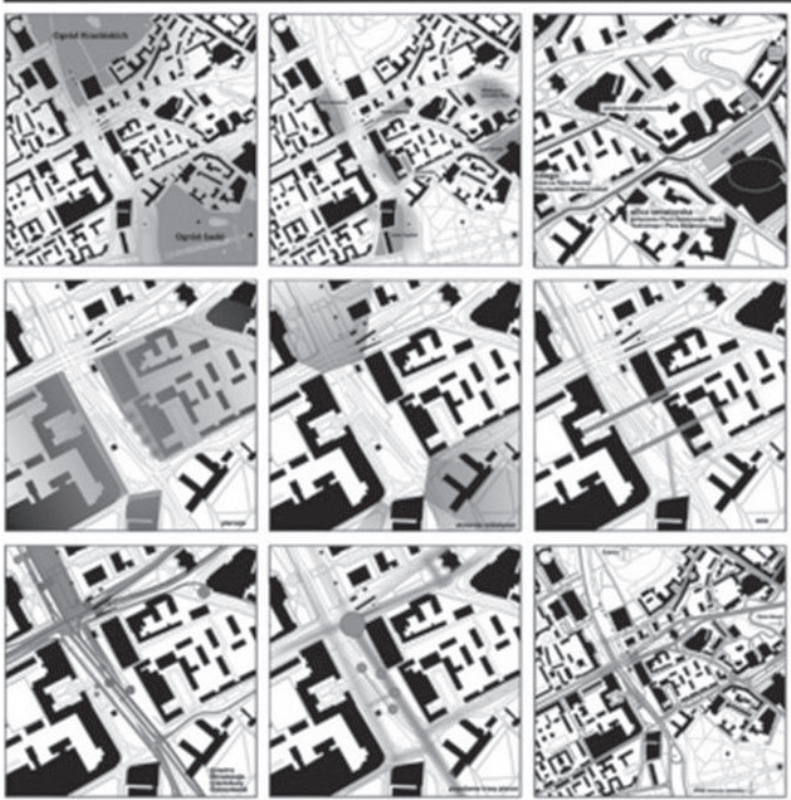

się predyspozycji poszczególnych uczestników zajęć. Wymiana poglądów na zdefiniowane problemy bywa owocna i może mieć wpływ na dalsze analizy własne, zazwyczaj utwierdza studentów w dokonanych zapisach głównych idei, cech, wskazań projektowych, nieraz też pozwala je dokładniej sformułować. Jest to również okazja do praktycznego sprawdzenia kompletności analiz wejściowych przeprowadzanych przez poszczególne osoby 9

\footnotetext{
${ }^{9}$ Przy tej okazji omawia się również techniczną stronę i metody prowadzenia tego typu prezentacji, zwracając uwagę na ich mocne i słabe strony, również w obszarze językowym.
}

RELACJA 0. SASKI - 0.KRASIŃSKICH

RELACJAZ PLACAMI TEATRU CAPITOL, KINA MURANÓW ORAZ POZOSTAKYMI

ODTWORZENIE RELACJI PLAC BANKOWY-TEATRALNY-ZAMKOWY

\section{DOMKNIECIE PIERZEI PLACU Il. 3. Karty z analizy}

urbanistycznej. Synteza hasłowa zapisana w prezentacji przedstawianej przez studenta i w zeszycie A3

(oprac. A. Rusinowska, źródło: archiwum WA PW)

\section{ODCIAŻENIE OD RUCHU SAMOCH. IPARKINGÓW \\ PRZENIESIENIE PRZYSTANKÓW \\ POZOSTANIE W RELACJI Z WËZLEM KOMUNIKACYJNYM}

Fig. 3. Cards from the urban analysis. A keyword synthesis included in the presentation prepared by a student and in A3 notebook (elaborated by A. Rusinowska, source: archive of FA WUT)
The second stage of work consists in illustrating verbal, slogan ${ }^{10}$ conclusions from individual analyses in the form of graphic, painting and sculptural works (Fig. 4) ${ }^{11}$. It is important to realize that this is not an easy stage and it is certainly different from the previous academic design experience. The form of artistic works does not have to

\footnotetext{
10 Slogans are treated as artwork titles.

11 It is recommended to first make sketches looking for graphic, painting and sculptural compositions in various techniques, which are rather not familiar to students and it is advisable to experiment with new tools. After completing the sketch diagnosis, students may (but do not have to) choose one technique to continue further art studies.
} 
analizy - podsumowanie

KSIAŻ̇E DRUCKI - LUBECKI: KONSERWATYSTAIREALISTA, ROZWÓJ PRZEMYSKUI GOSPODARKI, DYPLOMACJA SUROWY REALIZM - ENERGICZNY ROZWÓJ - POZYTYWISTA CZASÓW ROMANTYCZNYCH - "BOHATER NIESWOJEJ EPOKI"

Il. 4. Karta $\mathrm{z}$ podsumowania analiz. Synteza hasłowa stanowiąca materiał wejściowy do studiów artystycznych, zapisana w prezentacji przedstawianej przez studenta i w zeszycie A3 (oprac. A. Rusinowska, źródło: archiwum WA PW)

Fig. 4. A card with a summary of analyses. A keyword synthesis constituting an input materia for artistic studies, recorded in the presentation by the student and in A3 notebook

(elaborated by A. Rusinowska, source: archive of FA WUT)
HISTORIA: ZMIANY - BRAK LINIIUL RYMARSKIJ, OSI CORAZZIEGO, POLACZEŃ Z OKOLICA, RÓŻNORODNOSCE STYLÓW ODCIAZŻENIE - PODKREŚLENIE

ZABUDOWA: PROBLEMY - RÓZZNICE WYSOKOSCIOWE ISTYLOWE OBU PIERZEI, PODZIAL PLACU, BRAK DOMKNIĘC DOMKNIECIE - KADROWANIE - INDENTYFIKOWANIE

RELACJE: POKACZENIE PLACÓW, OGRODÓW, PODKREŚLENIE RELACJI PIESZJJW STRONE STAREGO MIASTA

POWIAZANIE (Z OGRODAMI, Z PLACEM TEATRALNYM I ZAMKOWYM)

KOMUNIKACJA: POTZREBA RZESUNIE_CIA PRZYSTANKÓW, OGRANICZENIE ILOSCI PASÓWI IRUCHU SAMOCHODOWEGO ROZLUŹNIENIE - ZAGESZZZZENIE - SWOBODA

FUNKCJE: URZĘYY, TEATRY, KINO, RESTAURACJE - MOZZLIWE STWORZENIE PRZESTRZENILACZACEJ OBIEKTY

POWIAZANIE (Z INNYMI FUNKCJAMI) ODCIAŻENIE (OD POWAGI REPREZENTACYJNEJ FUNKCJI)
Drugi etap pracy polega na zobrazowaniu słownych, hasłowych ${ }^{10}$ wniosków $\mathrm{z}$ poszczególnych analiz w formie prac graficznych, malarskich i rzeźbiarskich (il. 4) ${ }^{11}$. Trzeba zdać sobie sprawę, że nie jest to łatwy etap, jest z pewnością odmienny od dotychczasowych doświadczeń akademickich dotyczących projektowania. Forma prac plastycznych nie musi odnosić się wprost do zagadnień przestrzennych, choć często się na nich opiera, zaleca się wręcz wyabstrahowanie kompozycji plastycznych od bezpośrednich uwarunkowań przestrzenią placu. Prace artystyczne ilustrują wyłącznie hasła będące wnioskami $\mathrm{z}$ analiz ${ }^{12}$. Dopuszcza się na tym etapie daleko idącą indywidualizację studiów artystycznych. Bardzo ważna jest w tym miejscu rola prowadzącego zajęcia - tutora. Odmienność metody może sprawiać i sprawia niekiedy trudności, u niektórych może pojawiać się pustka twórcza - nie wiadomo co rysować. Towarzyszenie i wsparcie jest wskazane, animowanie aktywności pomimo bariery warsztatu, braku odwagi etc. należy do tutora i konsultantów z poszczególnych dyscyplin artystycznych, to jest ich podstawowe zadanie na tym etapie pracy. $\mathrm{W}$ trakcie

${ }^{10}$ Hasła są traktowane jak tytuły prac plastycznych.

11 Zaleca się wykonanie najpierw szkiców poszukujących kompozycje graficzne, malarskie i rzeźbiarskie w różnych technikach, raczej niekoniecznie znanych studentom, wskazane jest eksperymentowanie z nowymi narzędziami. Po wykonaniu rozpoznania szkicowego studenci mogą (ale nie muszą) wybrać jedną technikę do kontynuowania dalszych studiów plastycznych.

12 Bardzo istotne jest skupienie uwagi na obrazowaniu hasła, bez bezpośredniego odnoszenia się do tematu. Takie założenie pozwala na uwolnienie ekspresji twórczej studentów, oderwanie od szkolnego, często dość nieporadnego odwzorowywania zastanych układów przestrzennych. Powiązanie $\mathrm{z}$ tematem projektu zostało już zapisane $\mathrm{w}$ haśle w wyniku jego wykreowania w oparciu o wcześniejsze analizy. Całość wiedzy, dotychczasowych studiów wstępnych pracuje już w wyobraźni studenta. Skupienie uwagi wyłącznie na oddaniu sensu hasła pozwala całościowo i w sposób pełny wykorzystać zdobyte i przetworzone informacje. Bez zagrożenia dominacją pojedynczej, narzucającej się okresowo cechy. refer directly to spatial issues, although it is often based on them, it is even recommended to abstract artistic compositions from the direct determinants of the square's space. The works of art illustrate only the slogans which are the conclusions from these analyses ${ }^{12}$. A far-reaching individualization of artistic studies is allowed at this stage. The role of the lecturer - tutor is very important here. The distinctness of the method may cause and sometimes causes difficulties, for some there may be a creative emptiness - it is not known what to draw. Accompaniment and support is advisable. Animating the activity despite the barrier of the workshop, lack of courage, etc. belongs to the tutor and consultants from individual artistic disciplines. This is their main task at this stage of work. During this stage, more or less after the completion of the first sketches, a review of the works takes place with the participation of a commentator, i.e., a practicing architect who has not participated in the classes so far. During the review individual students present their works, explain their way of thinking, the concept, and the intentions of further artistic attempts. Everyone is invited to present their opinion. Important for the creative process are the comments of a commentator who knows the subject and views the resulting works in a completely fresh and new way. As a result of overcoming the initial difficulties, many works are created, which, in the course of

${ }^{12}$ It is very important to focus on the depiction of the slogan without referring to the topic directly. Such an assumption allows students to release their creative expression, to detach from the school, often quite clumsy representation of existing spatial systems. The link with the project topic has already been recorded in the slogan as a result of its creation on the basis of previous analyses. All the knowledge of the preliminary studies conducted so far, already works in the student's imagination. Focusing only on reflection of the meaning of the slogan allows students to comprehensively and fully use the information obtained and processed. Without the threat of the dominance of a single, periodically dominant trait. 

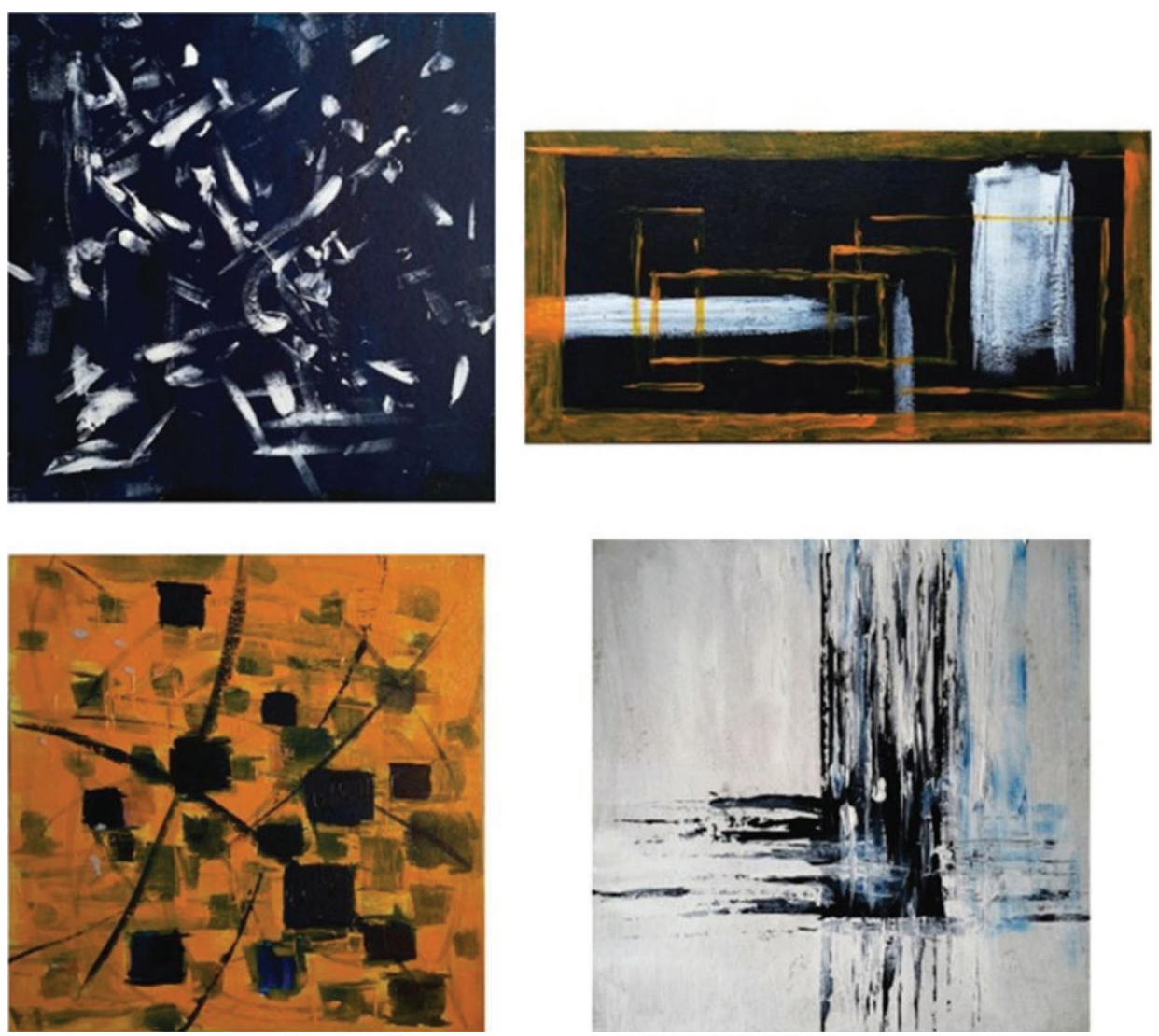

Il. 5. Prace malarskie odpowiadające wnioskom zapisanym na podstawie analiz (por. il. 4). Kopie prac zawarte w pracy studenckiej w zeszycie A3 (autor: A. Rusinowska, źródło: archiwum WA PW)

Fig. 5. Painting works corresponding to the conclusions drawn on the basis of the analyses (cf. Fig. 4). Copies of works included in the student's work in A3 notebook (elaborated by A. Rusinowska, source: archive of FA WUT)

trwania tego etapu, mniej więcej po zakończeniu pierwszych szkiców odbywa się przegląd prac z udziałem komentatora, architekta praktyka, który nie uczestniczył do tej pory w zajęciach. Podczas przeglądania poszczególne osoby przedstawiają swoje prace, wyjaśniają sposób myślenia, koncept, zamierzenia dalszych prób plastycznych. Wszyscy są zaproszeni do zaprezentowania swojej opinii. Istotne dla procesu twórczego są uwagi komentatora znającego temat, a patrzącego na powstałe prace w całkowicie świeży, nowy sposób. W wyniku przełamania początkowych trudności powstaje wiele prac, które w toku korekt i dyskusji będą stanowić materiał wstępny do ostatniego etapu projektu (il. 6 i 7).

Etap trzeci, końcowy, polega na odnalezieniu odpowiedniej formuly dla przeniesienia formy plastycznej - uzyskanej w toku studiów artystycznych na podstawie haseł z analiz wejściowych - na koncepcję architektoniczną obiektu upamiętniającego, projektu zagospodarowania terenu placu Bankowego. Studenci proszeni są o autorskie wskazanie wybranej pracy lub ich serii, które stanowić będą plastyczny materiał wstępny do projektu ${ }^{13}$. Oczeku-

13 Znaczenie w tym momencie ma zdobycie umiejętności dokonywania wyboru. Może odbywać się to w toku rozmów z tutorem, ważenia cech, autoanalizy, pogłębionej refleksji, dostrzegania samokreujących się aspektów przestrzennych. Warto przy tej okazji pamiętać, że podczas wykonywania prac plastycznych uwaga studentów skupiona była na istocie cech wskazanych w wyniku wstępnych analiz projektowych, zatem zadanie powrotu do formy projektowej polega na umiejętnym interpretowaniu powstałych obrazów czy rzeźb, prowadzącym do dostrzeżenia w nich kształtów architektonicznych. corrections and discussions, will constitute a preliminary material for the final stage of the project (Figs. 6, 7).

The third and final stage consists of finding an appropriate formula for transferring the artistic form - obtained in the course of artistic studies on the basis of entries from input analyses - to the architectural concept of the commemorative object, the design of development of the Bankowy Square area. Students are asked to select a work or a series of works, which will be the preliminary plastic material for the project ${ }^{13}$. Students are expected to easily discover the ideological connections of the resulting works with the commemoration of the prince. In most cases, it turns out that students make a more or less unexpected discovery of the spatial relations of their artworks with the idea of commemorating Prince Ksawery Drucki-Lubecki and the site. This leads to a fairly efficient record of these connections and assigning them to specific architectural solutions and the development of Bankowy Square. The form of commemoration is then recorded in the form of projections, sections, or possibly a facade. It can be presented in a painting formula related to architec-

13 At this point, it is important to learn how to make a choice. It may take place in the course of conversations with the tutor, weighing of features, self-analysis, in-depth reflection, noticing of self-developing spatial aspects. At the same time, it is worth remembering that during the performance of artistic works, students' attention was focused on the essence of the features indicated as a result of preliminary design analyzes, so the task of returning to the design form consists in skillful interpretation of the resulting paintings or sculptures, leading to the noticing of architectural shapes in them. 

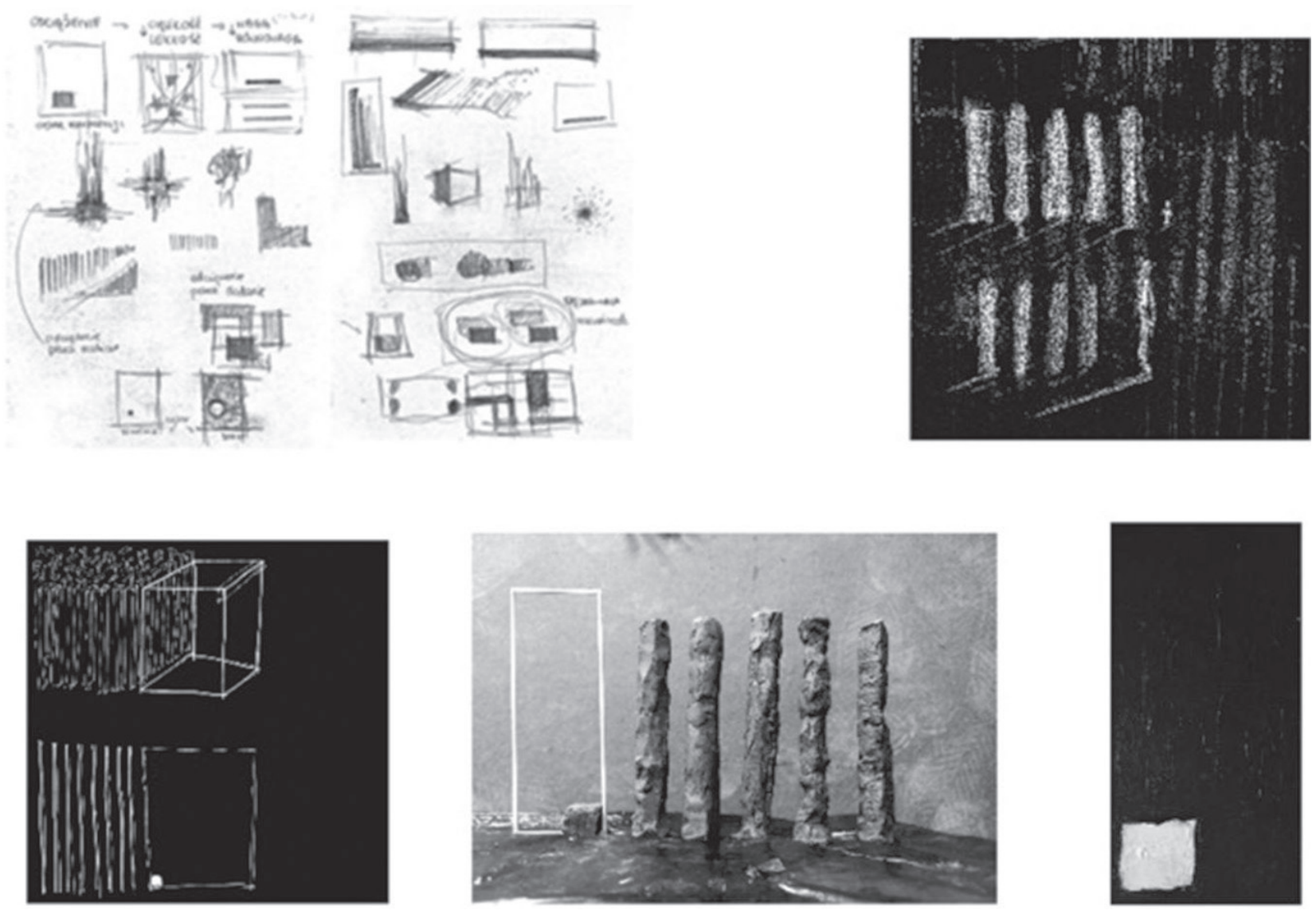

Il. 6. Prace rysunkowe, graficzne, rzeźbiarskie, stanowiące ciąg myślowy, odpowiadające wnioskom zapisanym na podstawie analiz. Kopie prac zawarte w pracy studenckiej w zeszycie A3 (autor: A. Rusinowska, źródło: archiwum WA PW)

Fig. 6. Drawing, graphic and sculptural works, constituting a string of thought, corresponding to the conclusions drawn on the basis of analyses. Copies of works included in the student's work in A3 notebook (elaborated by A. Rusinowska, source: archive of FA WUT)

je się, że studenci w prosty sposób odkryją powiązania ideowe powstałych prac z upamiętnieniem osoby księcia. W większości przypadków okazuje się, że studenci dokonują mniej lub bardziej niespodziewanego odkrycia związków przestrzennych swojej pracy plastycznej z ideą upamiętnienia księcia Ksawerego Druckiego-Lubeckiego i terenem lokalizacji. Prowadzi to do dość sprawnego zapisu tych powiązań i przypisania ich konkretnym rozwiązaniom architektonicznym i zagospodarowaniu placu Bankowego. Forma upamiętnienia zostaje następnie zapisana w postaci rzutów, przekrojów, ewentualnie elewacji. Może być przedstawiona w formule malarskiej powiązanej z rzutami architektonicznymi (il. 7). Zakłada się pełną dowolność w tej mierze, wskazane są co semestr wyłącznie ramy formatowe i zakresowe, techniki realizacji pozostawia się studentom, zazwyczaj idą one do końca w parze z pracami plastycznymi wykonanymi w drugim etapie pracy.

Projekt koncepcji miejsca pamięci jest obecnie ${ }^{14}$ prezentowany w formie planszy o szerokości $1 \mathrm{~m}$ i wysokości do $2 \mathrm{~m}$ ukazującej ideę upamiętnienia oraz zeszytu w formacie A3 zawierającego wszystkie wykonane analizy wraz

$14 \mathrm{~W}$ poprzednich latach zmieniały się zakresy prezentacji, od trzech plansz $70 \times 100 \mathrm{~cm}$ w układzie poziomym i makiety, przez trzy plansze, makietę i osobną planszę idei w dowolnym formacie po obecny zakres. tural projections (Fig. 7). Full freedom is assumed in this respect, only the format and scope frames are indicated every semester. The techniques of implementation are left to students and they usually go to the end in line with the art works made in the second stage of the work.

The project of the concept of the memorial site is currently ${ }^{14}$ presented in the form of a board $1 \mathrm{~m}$ wide and up to $2 \mathrm{~m}$ high showing the idea of commemoration and a notebook in A3 format containing all the analyses and conclusions, copies or originals of artistic studies, sketches and design drawings as well as projections, sections, façades, land development plan. A model of the square is also a mandatory component of the concept presentation.

\section{Results}

For the design process based on artistic studies, two components connecting the subsequent stages of work are important. The first one takes place when the keywords summarizing the analysis are indicated. There is

${ }^{14}$ In previous years, the scope of presentations has changed, from three $70 \times 100 \mathrm{~cm}$ boards in a horizontal layout and models, through three boards, a model and a separate idea board in any format, to the current scope. 

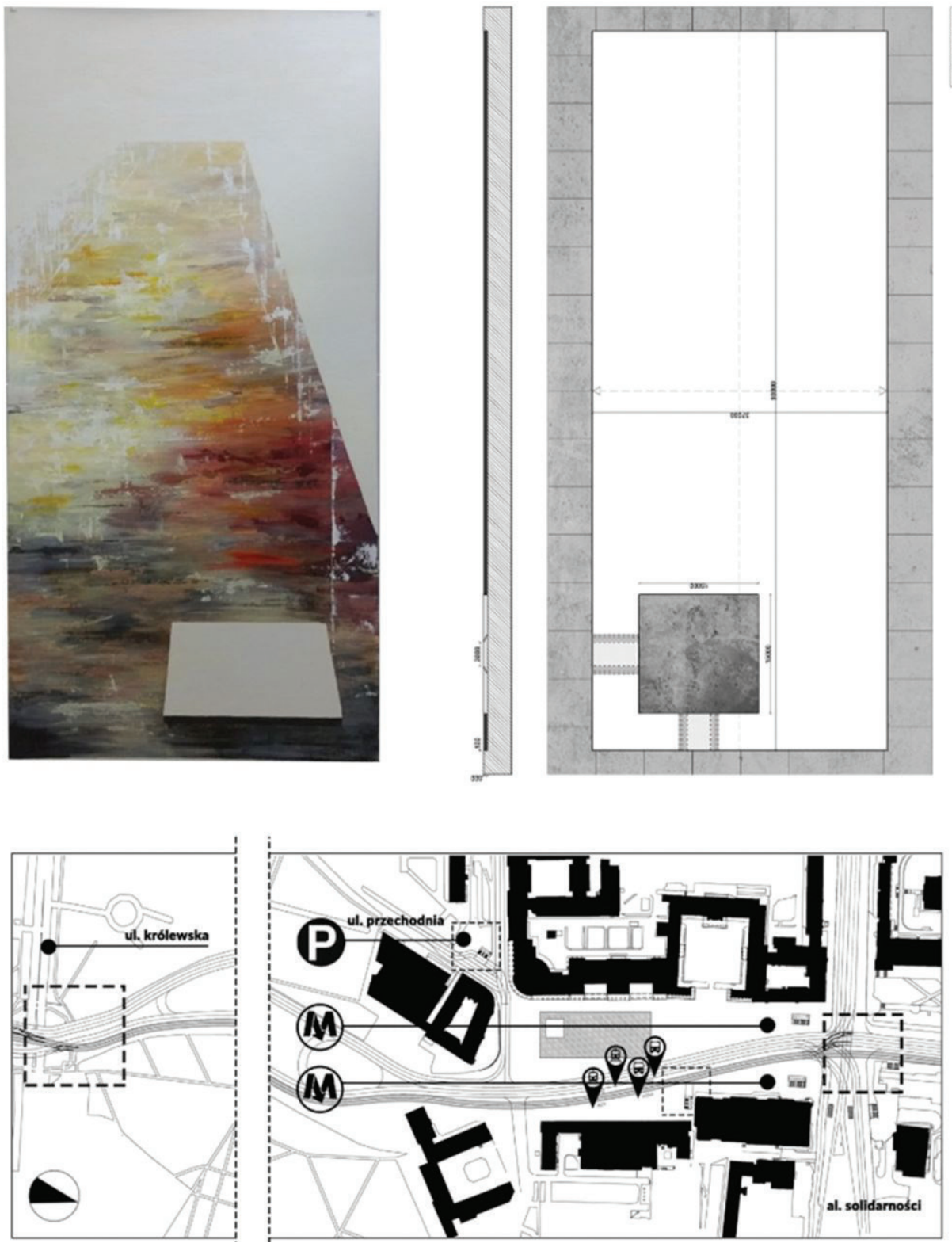

Il. 7. Praca malarska prezentująca ideę projektu upamiętnienia, rzut z projektu i schemat przestrzenny z projektu (por. il. 5 i 6). Kopie prac zawarte w pracy studenckiej w zeszycie A3

(autor: A. Rusinowska, akryl, $100 \times 200 \mathrm{~cm}$, źródło: archiwum WA PW)

Fig. 7. A painting work presenting the idea of the commemoration project, projection of the design and a spatial diagram of the design (cf. Figs. 5 and 6). Copies of works included in the student's work in A3 notebook (elaborated by A. Rusinowska, acrylic, $100 \times 200 \mathrm{~cm}$, source: archive of FA WUT) z wnioskami, kopie lub oryginały studiów artystycznych, szkice i rysunki projektowe oraz rzuty, przekroje, elewacje, projekt zagospodarowania terenu. Obowiązkowym składnikiem prezentacji koncepcji jest również makieta placu.

\section{Rezultaty}

Dla procesu projektowego opartego na studiach artystycznych istotne znaczenie mają dwa składniki spajające kolejne etapy pracy. Pierwszy z nich następuje w momencie wskazania haseł podsumowujących analizy. Nie ma przy tym miejsca na zestawianie wniosków i wyprowadzanie pojedynczego czy sumarycznego zespołu wytycznych projektowych. To zadanie mają spełnić studia artystyczne. Po przeprowadzeniu wnikliwych analiz wejściowych w sformułowanych hasłach zawierają się wszystkie istotne dane, z punktu widzenia wagi decyzji projektowych.

Podstawą dla studiów artystycznych jest zatem zbiór haseł stanowiących pretekst do działań twórczych, pod- no room for compiling conclusions and deriving a single or summary set of design guidelines. This task is to be fulfilled by artistic studies. After conducting in-depth input analyses, the formulated slogans contain all relevant data from the point of view of the importance of design decisions.

The basis for artistic studies is therefore a set of slogans constituting a pretext for creative activities, during which the content of the created slogans is transferred into the area of art. In this way, through the activity of the conducted synthesis, essential content is naturally selected, the most important part gains an advantage in creative activities and receives the final form of artistic works that contain important premises concerning the main topic of the design and the localization context (Figs. 8, 9).

The second important moment in the design process is noticing the potential in the created artistic work that could be the theme of the object (Fig. 6) or even the structure of the entire establishment, development of Bankowy Square, while maintaining the idea of commemorating 

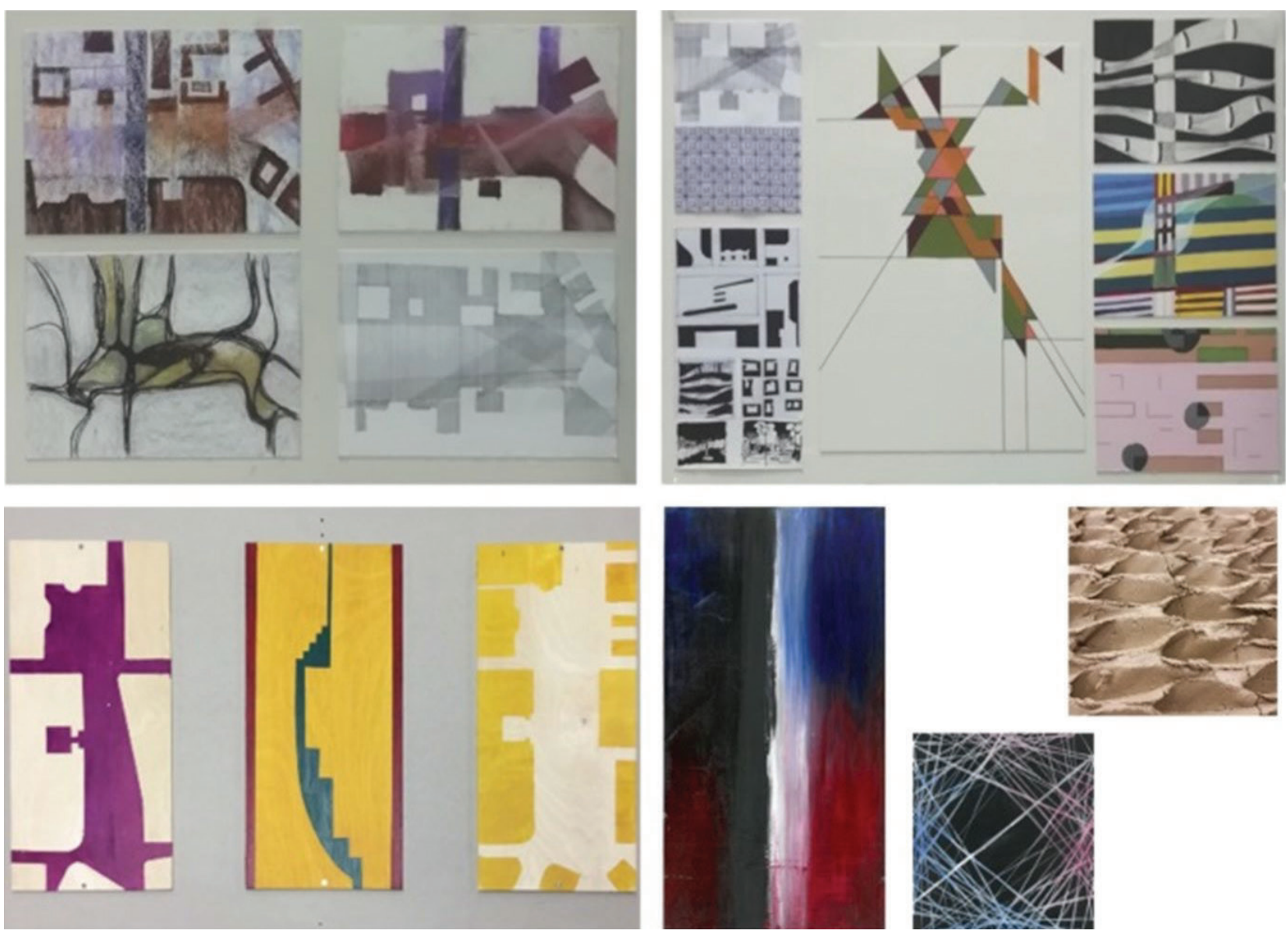

Il. 8. Prace malarskie, graficzne i rzeźbiarska, odpowiadające wnioskom zapisanym na podstawie analiz, przykłady autorstwa różnych studentów. Prace zawarte w pracy studenckiej w zeszycie A3 (autorzy: plansze graficzne u góry - A. Parzyszek, trzy prace u dołu po lewej - A. Bartczak, po prawej - E. Zientała, źródło: archiwum WA PW)

Fig. 8. Painting, graphic and sculptural works, corresponding to the conclusions drawn on the basis of analyses, examples of works by various students. Works included in the student's work in A3 notebook

(authors: graphic boards at the top - A. Parzyszek, three works at the bottom to the left - A. Bartczak, on the right - E. Zientała, source: archive of FA WUT)

czas których następuje przeniesienie w obszar sztuki treści zawartych w utworzonych hasłach. W ten sposób przez aktywność prowadzonej syntezy następuje naturalne selekcjonowanie istotnych treści, te najważniejsze uzyskują przewagę w działaniach twórczych i otrzymują finalną formę dzieł artystycznych, które zawierają istotne przesłanki dotyczące głównego tematu projektowego i kontekstu lokalizacyjnego (il. 8 i 9).

Drugim ważnym momentem w procesie projektowym jest dostrzeżenie w powstałej pracy artystycznej potencjału mogącego stanowić motyw obiektu (il. 6) czy wręcz strukturę całości założenia, zagospodarowania placu Bankowego przy jednoczesnym zachowaniu idei poświęconej upamiętnieniu osoby księcia. Praktycznie studenci dostają w wyniku studiów artystycznych ,gotowe” rozwiązania przestrzenne, a proces ich definiowania i kojarzenia z konkretną formą architektoniczną zaczyna się równolegle z pracą nad nimi.

Ostatni etap studiów nad projektem dotyczy de facto jedynie umiejętnego zaprezentowania wypracowanej w ten sposób idei upamiętnienia. Projekty zatrzymują się the prince. As a result of artistic studies, students receive "ready" spatial solutions, and the process of defining them and associating them with a specific architectural form begins simultaneously with work on them.

The last stage of studies on the project concerns only the skillful presentation of the idea of commemoration developed in this way. The projects stop at the conceptual stage, primarily shaping the form. The advancement of detailed solutions regarding functions and details depends to a large extent on the student's predisposition and is highly individualized and varied (Fig. 10).

The classes methodically, step by step, lead the participants through consecutive predefined stages. Summing up, it should be noted that the interest of students in this form and method of work has been growing year by year. The projects are distinguished by their slightly "competitive" nature. From year to year, this process is assessed by subsequent participants, and on its basis, it is modified every year in various scopes. Despite the fourth semester of teaching according to the formula described above, none of the students' projects (42 works) was repeated in 

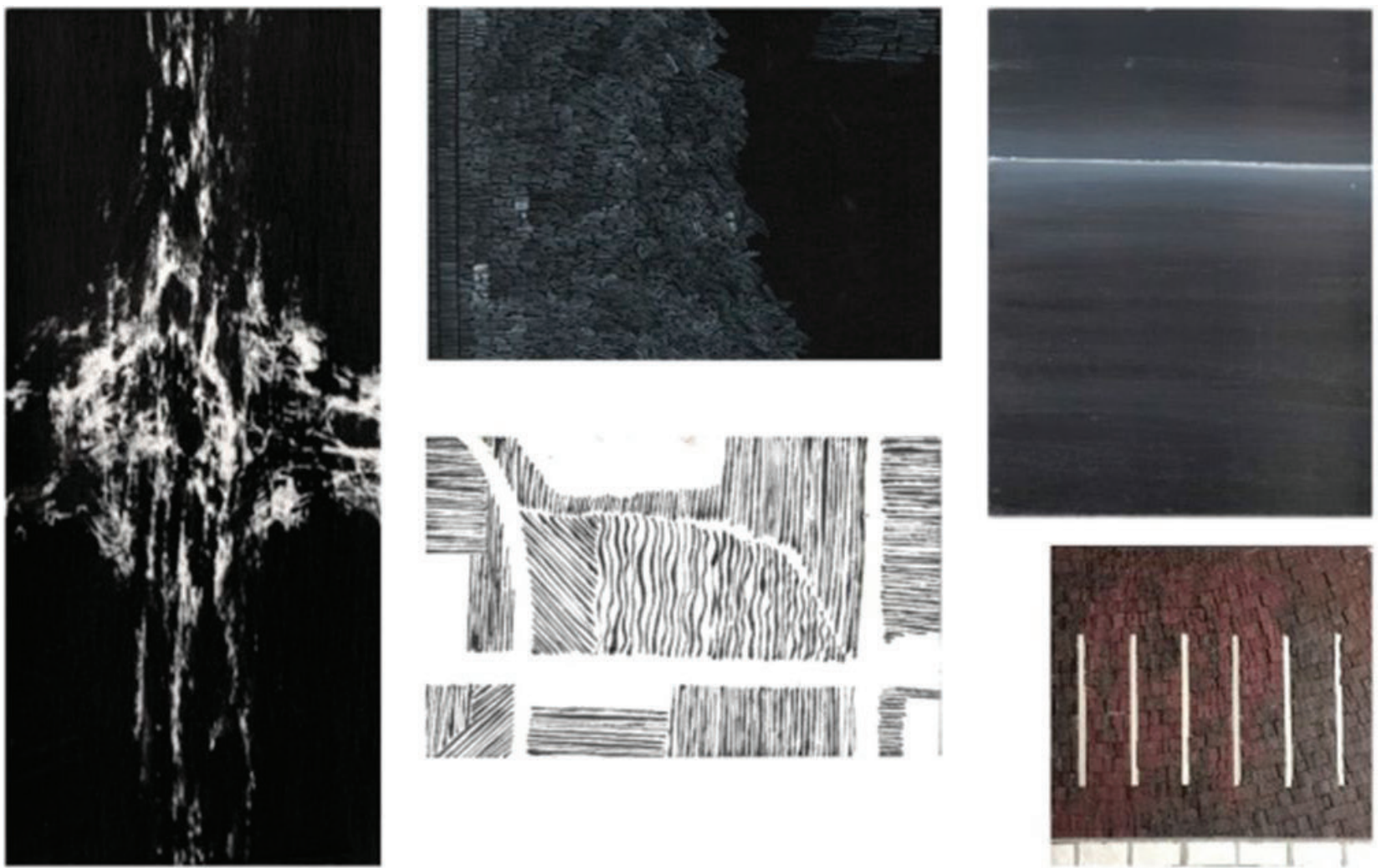

Il. 9. Prace graficzne odpowiadające wnioskom zapisanym na podstawie analiz, przykłady autorstwa różnych studentów. Prace zawarte w pracy studenckiej w zeszycie A3 (autorzy: praca u góry po lewej i w środku - M. Mikos, w środku poniżej i u góry po prawej-K. Wojtczyk-Eluszkiewicz, po prawej - A. Gadomski, źródło: archiwum WA PW)

Fig. 9. Graphic works, corresponding to the conclusions drawn on the basis of analyses, examples of works by various students. Works included in the student's work in A3 notebook (authors: work at the top to the left and in the center - M. Mikos, in the middle below and at the top to the right $-\mathrm{K}$. Wojtczyk-Eluszkiewicz, on the right $-\mathrm{A}$. Gadomski, source: archive of FA WUT)

na etapie koncepcyjnym, kształtując przede wszystkim formę. Zaawansowanie rozwiązań szczegółowych, dotyczących funkcji i detalu, zależy w dużej mierze od predyspozycji studenta i jest dalece zindywidualizowane i zróżnicowane (il. 10).

Zajęcia, metodycznie, krok po kroku, prowadzą uczestników przez kolejne zdefiniowane etapy. Podsumowując, należy zauważyć, że z roku na rok rośnie zainteresowanie studentów tą formą i metodą pracy. Projekty wyróżniają się swoim nieco „konkursowym” charakterem. Z roku na rok proces ten jest poddawany ocenie kolejnych uczestników, na jej podstawie corocznie modyfikowany w różnych zakresach. Pomimo czwartego semestru prowadzenia zajęć według opisanej formuły żaden z powstałych projektów studenckich (42 prace) nie powtórzył się zarówno w sferze plastycznej, jak i w formie architektonicznej i zagospodarowania placu.

Jednym ze składników procesu dydaktycznego jest zawsze ocena pracy. W przypadku omawianej metody nie stosuje się żadnych form ocen przejściowych. Nacisk podczas trwania projektowania położony jest na animowanie dyskursu pomiędzy ich uczestnikami oraz wydobywanie pozytywów w przedstawianych pracach. Ocena efektów jest oceną aktywnego uczestniczenia w kolejnych etapach pracy, czyli odbycia pełnego procesu dydaktycznego. the visual sphere, or in the architectural form and arrangement of the square.

One of the components of the teaching process is always job evaluation. This method does not use any form of interim assessment. During the design phase, the emphasis is on animating the discourse between the participants and bringing out the positives in the presented works. The assessment of the results is an assessment of active participation in the subsequent stages of work, i.e., completing the full didactic process.

\section{Discussion}

According to the method described above, so far 42 works have been performed, which from the point of view of the author's experience is a considerable number, but objectively it is not a large number. Behind each project work there is a specific student who has individually addressed the proposed method. A vast majority of students fully applied it. Starting the work according to the described method requires overcoming various objective opposites, such as the routine consisting in getting used to a certain design method, such as internal pressure to achieve a good effect, or such as compliance with the formal requirements of the project presentation method, 

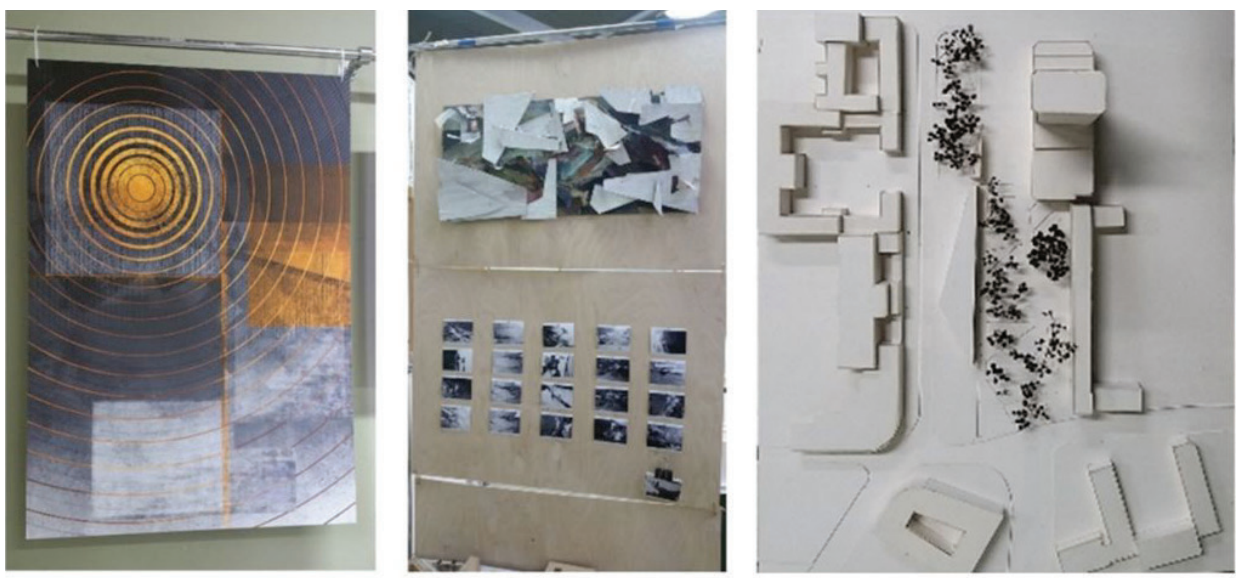

I1. 10. Prace finalne różnych autorów, u góry zdjęcia z wystawy z pracami prezentującymi ideę projektu (autorzy: od lewej

K. Matuszewski, obraz, akryl, $100 \times 140 \mathrm{~cm}$ collage - N. Słomczyński, makieta po prawej - E. Zientała, u dołu plansza projektowa - S. Grodzka,

źródło: archiwum WA PW)

Fig. 10. Final works by various authors, at the top photos from the exhibition with works presenting the idea of the project (authors: from the left:

K. Matuszewski, painting, acrylic, $100 \times 140 \mathrm{~cm}$,

collage - N. Słomczyński, model on the right - E. Zientała,

at the bottom a board design S. Grodzka, source: archive of FA WUT)

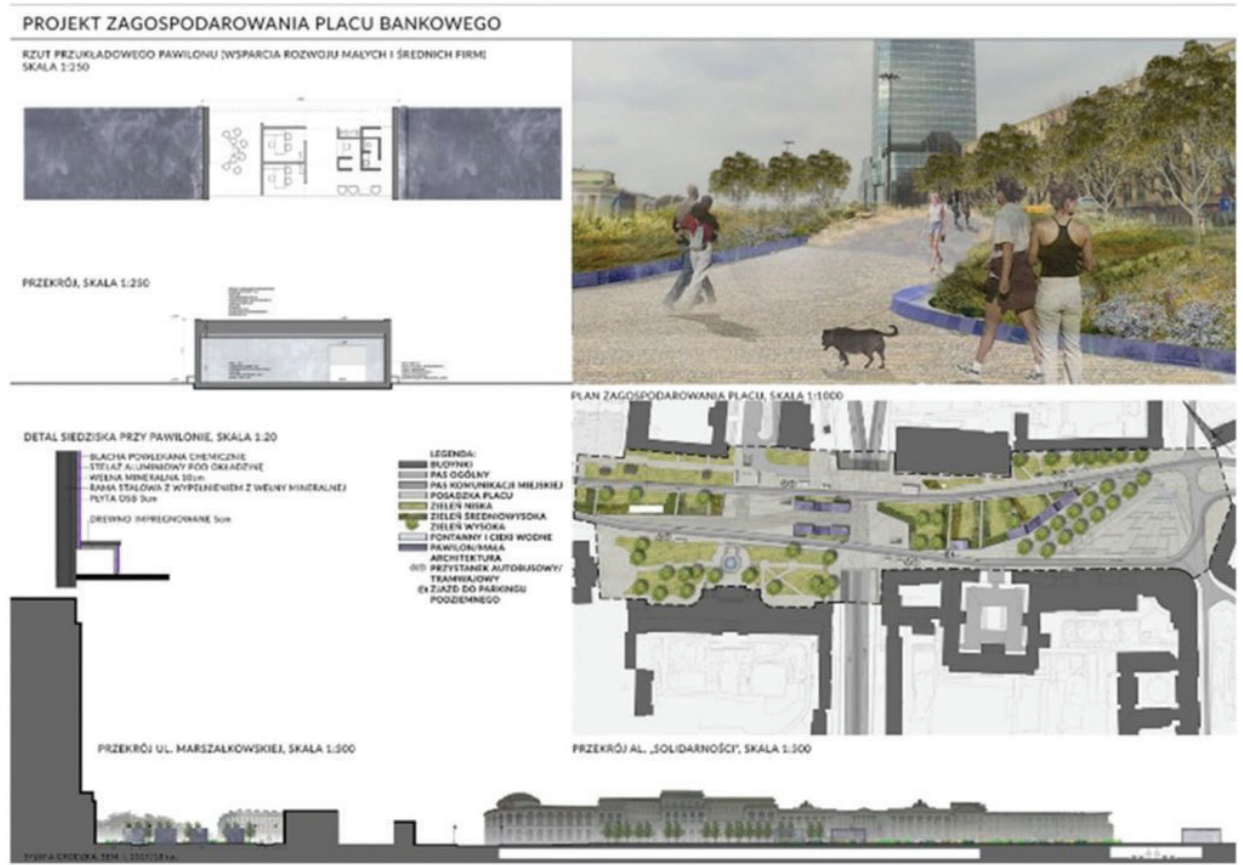

\section{Dyskusja}

Według opisanej metody wykonano dotychczas 42 prace, co z punktu widzenia doświadczeń autora jest liczbą znaczną, jednak obiektywnie nie jest ona duża. Za każdą pracą projektową stoi konkretny student, który odniósł się indywidualnie do zaproponowanej metody. Zdecydowana większość studentów zastosowała ją w pełni. Wejście $\mathrm{w}$ prace według opisanej metody wymaga pokonywania różnych obiektywnych przeciwieństw, takich jak rutyna polegająca na przyzwyczajeniu do określonego sposobu projektowania, jak wewnętrzna presja osiągnięcia dobrego efektu, jak przestrzeganie wymogów formalnych sposobu prezentacji projektu etc. ${ }^{15} \mathrm{~W}$ efekcie powstają prace o zróżnicowanej wartości architektonicznej. Jednak to nie ostateczny efekt projektowy decyduje o wartości ćwiczenia dla

15 Co roku, pomimo przekazywania sobie informacji przez studentów kolejnych roczników, pojawia się niedowierzanie, że nie będzie ocen cząstkowych, że będzie prowadzenie przez proces projektowy krok po kroku, a na koniec nie będzie oceniany efekt tylko całość pracy podczas semestru. etc..$^{15}$ As a result, works of various architectural value are created. However, it is not the final design outcome that determines the value of the exercise for an individual student. What is decisive is the path taken, the work, the new experience, change of mindset, broadening the knowledge, openness to joint activity. This, too, is probably the greatest value of this method. The examples presented are only a general background for the presented didactic method and one should not go into their details, evaluate or classify them. That should never be the goal.

The same applies to the issue of authorship. The teamwork in the profession of an architect is now an obvious thing veryone who works in a design team probably perfectly knows how the ideas of others often make us form innovative associations which are transformed into the final architectural form not only by us but also by others

15 Every year, in spite of sharing information by students of subsequent years, there is disbelief that there will be no partial grades, that there will be a step-by-step guiding through the design process, and at the end of the semester the effect will not be assessed but the overall work throughout the semester. 
pojedynczego studenta. Decyduje droga, którą odbył, praca, nowe doświadczenie, zmiana sposobu myślenia, poszerzenie wiedzy, otwarcie na wspólne działanie. To też stanowi prawdopodobnie największą wartość metody. Zaprezentowane przykłady to tylko ogólne tło dla przedstawionej metody dydaktycznej i nie należy wnikać w ich szczegóły, oceniać, klasyfikować. To nie powinno być nigdy celem.

Podobnie rzecz ma się z kwestią autorską. Zespołowość w zawodzie architekta jest obecnie oczywistością, każdy, kto pracuje w zespole projektowym, wie prawdopodobnie doskonale, sam z pewnością tego doświadczył, jak pomysły innych rodzą w nas kolejne, często odkrywcze skojarzenia, które niekoniecznie my sami, ale jeszcze inni zamieniają w ostateczną formę architektoniczną, do której uszlachetnienia z kolei również my przykładamy dłoń. Kto w takim przypadku jest autorem? Tego też warto nauczać przy okazji omawianej metody projektowania. Owa wymiana myśli z koleżankami i kolegami pomaga często dostrzec własny pomysł niejasno zarysowujący się w wyobraźni. Ma to również przełożenie na dalsze etapy pracy zawodowej, a szczególnie również badawczej, kiedy zamiast zazdrośnie strzec własnych odkryć, planów, pomysłów, powinniśmy, a wręcz jesteśmy powołani do ich upubliczniania dla dobra wspólnoty badawczej, aby inni, może zdolniejsi, mogli je rozwijać albo nie popełniać naszych błędów. Takie nastawienie do twórczości wpajamy studentom $w$ ramach naszej metody.

Warto zwrócić uwagę nie tyle na treść metody, ile raczej na prowadzenie zajęć w zgodzie z jakąkolwiek metodą. Jedną $z$ informacji pozyskanych od studentów jest właśnie ich zaskoczenie tym, że projektowanie może być sekwencją kolejnych zdefiniowanych kroków, a nie poszukiwaniem po omacku, na wyczucie albo według wyimaginowanych i oderwanych od realnych uwarunkowań założeń formalnych. Istnieje przekonanie, że jedną $\mathrm{z}$ akademickich powinności jest właśnie przedstawianie studentom konkretnych metod pracy, pozwalających na odnalezienie z czasem, w drodze kolejnych, konkretnych poszukiwań, być może ich własnej metody. Ale aby to zafunkcjonowało, winno się okazać pewną dozę tolerancji i odnajdywać w młodszych koleżankach i kolegach te dobre cechy, które należy pielęgnować, a jednocześnie próbować zrozumieć odmienność ich punktu widzenia, racji, potrzeb związanych z inną perspektywą od naszej, zawsze też pozostawiać im stosowną miarę samodzielności i pełnię wolności w dokonywaniu wyboru.

Może uda się wówczas wytworzyć umiejętność dostrzegania relacji między punktem, kreską i plamą dotyczących nie tylko zapisu idei architektonicznej, nauczania architektury rozumianej jako sztuka, ale jednocześnie podmiotowego postrzegania człowieka we wszystkich aspektach jego aktywności. Postrzegania człowieka nie na podstawie niejasnych, często obarczonych naszym ego wyobrażeń, ale rzetelnego przysłuchiwania i przyglądania się człowiekowi jako odrębnej osobie, z nastawieniem na poszukiwanie wartości przez nią prezentowanych. W ten sposób przez budowanie relacji podmiotowej pomiędzy ludźmi będziemy przyczyniać się do kształcenia architektów wrażliwych na realne potrzeby przyszłych użytkowników projektowanej przez nich architektury. and to the improvement of which we also contribute. Who is the author in this case? This is also worth teaching in the context of the discussed design method. This exchange of ideas with friends often helps to see one's own idea appearing vaguely in our imagination. This also translates into further stages of professional work, and especially research work, when instead of jealously guarding our own discoveries, plans and ideas, we should, or even we are called to make them public for the good of the research community, so that others, maybe more talented ones, could develop them or avoid our mistakes. We instill this attitude towards creativity in our students as part of our method.

It is worth paying attention not so much to the content of the method, but rather to the conducting of classes in accordance with any method. One of the information obtained from students is their surprise that designing can be a sequence of successive defined steps, and not a search in the dark, by feeling, or according to imaginary formal assumptions detached from real conditions. There is a belief that one of the academic duties is to present specific methods of work to students, allowing them to find over time, through subsequent, specific searches, perhaps their own method. But for this to work, one should show a certain amount of tolerance and find in younger colleagues those good qualities that should be nurtured, and at the same time try to understand the difference of their point of view, reasons, needs related to a different perspective from ours, and also always leave them an appropriate measure of independence and full freedom in making a choice.

Perhaps then it will be possible to develop the ability to perceive the relationship between a point, a line and a stain concerning not only the recording of an architectural idea, teaching of architecture understood as art, but also the subjective perception of man in all aspects of his activity. Perceiving man not on the basis of vague ideas often burdened with our ego, but on the honest listening and observing man as a separate person, with an attitude of searching for the values presented by that person. In this way, by building a subjective relationship between people, we will contribute to educating architects who are sensitive to the real needs of future users of the architecture they design.

As a result of applying the presented method of teaching design on the basis of artistic disciplines, the way of perceiving the design function is changing. Transformation of attitudes represented by students is revolutionary, it takes the form of discovering one's own path, opening up to new creative forces, often dormant so far between occasional design attempts. Finally, the reference to art in the design process makes it possible to establish a thread of relations with the often forgotten original ideas of the founders of the Bauhaus, as well as the FA WUT. Humanistic ideas, blurred throughout the century, can be successfully reborn in the projects of the young generation who discover that architecture is art after all.

Students who confidently started designing on the basis of art disciplines deserve special thanks from the author of this article. Thanks to their efforts, art has a chance to practically return to the architect's design workshop. 
W wyniku stosowania przedstawionej metody nauczania projektowania $\mathrm{w}$ oparciu o dyscypliny artystyczne następuje przemiana sposobu postrzegania funkcji projektowania. Przemiana postaw reprezentowanych przez studentów ma charakter rewolucyjny, przybiera formę odkrycia własnej ścieżki, otwarcia na nowe siły twórcze drzemiące często do tej pory pomiędzy dorywczymi próbami projektowymi. Wreszcie odwołanie do sztuki w procesie projektowym pozwala nawiązać nić relacji z zapomnianymi już często pierwotnymi ideami założycieli Bauhausu, a również WA PW. Rozmyte na przestrzeni całego wieku humanistyczne idee mogą się z powodzeniem odradzać w projektach młodego pokolenia odkrywającego, że architektura jest jednak sztuką.

Studenci, którzy z zaufaniem przystąpili do projektowania w oparciu o dyscypliny sztuki, zasługują na szczególne podziękowania ze strony autora tego artykułu. Dzięki ich wysiłkowi sztuka ma szansę praktycznie powrócić do warsztatu projektowego architekta. Podobnie należy dziękować wymienionym wcześniej kolegom architektom i artystom, którzy zdecydowali się wesprzeć autora w prowadzeniu omawianych ćwiczeń.

Dzieląc się w ten sposób pomysłem formuły zajęć projektowych, autor wyraża nadzieję na otwarcie szerszej dyskusji w architektonicznym środowisku akademickim na temat włączania dyscyplin sztuki do procesów projektowych. Przywrócenie ich prymatu w twórczych procesach projektowych wydaje się konieczne. Również liczy na opinie koleżanek i kolegów, być może prowadzących podobne ćwiczenia.
Similarly, thanks should be given to the aforementioned fellow architects and artists who decided to support the author in conducting the exercises described above.

By sharing the idea of the formula for design classes in this way, the author hopes to open a wider discussion in the architectural academia on the topic of incorporating art disciplines into design processes. It seems necessary to restore their primacy in creative design processes. Also, the author counts on the opinions of his colleagues, who perhaps have been conducting similar exercises.

\section{Translated by Jadwiga Andrejczuk-Panasiuk}

\section{Bibliografia/References}

[1] Warszawska Szkoła Architektury 1915-1965. 50-lecie Wydziału Architektury Politechniki Warszawskiej, J. Zachwatowicz (red.), WA PW, Warszawa 1967.

[2] Kamiński Z., Dzieje życia w pogoni za sztuka, PAX, Warszawa 1975

[3] Gropius W., Petnia architektury, Karakter, Kraków 2014.
[4] Mies in Berlin, T. Riley, B. Bergdoll (eds.), The Museum of Modern Art, Monachium-Berlin-London-New York 2002.

[5] Le Corbusier, W stronę architektury, CA, Warszawa 2012.

[6] Szczerski A., Cztery nowoczesności, DodoEditor, Kraków 2015.

[7] Kandyński W., Punkt i linia a płaszczyzna, Officyna, Łódź 2019.

\section{Streszczenie}

Artykuł jest poświęcony propozycji wdrożenia w projektowanie architektoniczne dyscyplin artystycznych na etapie studiów magisterskich. Celem przywołania aktywnego udziału sztuki w tworzeniu architektury jest poszukiwanie jej stale odnawialnego wyrazu, sensu głównych idei kształtujących architekturę. Dla pokazania tła wskazane są odniesienia do przeszłości, do czasu Bauhausu, który jako ruch twórczy wskazywał sztukę jako istotną część kreacji architektonicznej. Kreując i przyglądając się nauczaniu dyscyplin artystycznych na WA PW, należy dostrzec wyraźne zmiany. Podaje się do dyskusji pomysł ściśle zdefiniowanej metody projektowania w oparciu o dyscypliny sztuki. Przedstawiając zastosowaną metodę i płynące z niej doświadczenia liczy się na jej upowszechnienie. Istotną część stanowią wnioski z przeprowadzonych studiów. W edukacji artystycznej prowadzonej we wskazany sposób tracą na znaczeniu zagadnienia czysto warsztatowe, przewagę zyskuje umiejętność syntetycznego zapisu myśli jako zapisu i przekazu informacji w formach artystycznych, malarstwie, grafice, rzeźbie, kolażu. Jednocześnie obserwuje się, w jaki sposób wprowadzone działania artystyczne pomagają w otwieraniu nowych obszarów twórczych w dydaktyce w obszarze projektowania architektonicznego i urbanistycznego.

Slowa kluczowe: architektura, sztuka, dydaktyka, projekt

\section{Abstract}

This article discusses the proposals for implementing artistic disciplines into architectural design at the stage of master's studies. The aim of referring to the active participation of art in the creation of architecture is to search for its constantly renewable expression, the sense of the main ideas shaping architecture. In order to show the background, references to the past are made, to the time of the Bauhaus which as a creative movement pointed to art as an essential part of architectural creation. When creating and observing the teaching of artistic disciplines at the Faculty of Architecture of Warsaw University of Technology, significant changes can be noticed. The idea of a strictly defined designing method based on the disciplines of 
art is discussed. Presenting the method used and the experience derived from it, we hope for its dissemination. The conclusions from the research constitute a significant part. In artistic education conducted in the indicated way, purely workshop issues lose their significance, while more emphasis is placed on the ability to synthesize thoughts as a record and transmission of information in artistic forms, painting, graphics, sculpture, collage. At the same time, we observe how the introduced artistic activities help in opening new creative areas in education in the field of architectural and urban design.

Key words: architecture, art, education, architectural design 